NBER WORKING PAPER SERIES

\title{
HOW DOES GOVERNMENT BORROWING AFFECT CORPORATE FINANCING AND INVESTMENT?
}

\author{
John Graham \\ Mark T. Leary \\ Michael R. Roberts \\ Working Paper 20581 \\ http://www.nber.org/papers/w20581
}

\author{
NATIONAL BUREAU OF ECONOMIC RESEARCH \\ 1050 Massachusetts Avenue \\ Cambridge, MA 02138 \\ October 2014
}

This paper previously circulated under the title, "Financial Crowding Out." We thank Andy Abel, Ravi Bansal, Effi Benmelech, Joao Gomes, Robin Greenwood, Boyan Jovanovich, Stefan Nagel, Josh Rauh, Ken Singleton, Jeremy Stein, Amir Sufi, Jules Van Binsbergen, Amir Yaron; seminar participants at Arizona State University, Duke University, London Business School, London School of Economics, Miami University, Notre Dame, MIT, Ohio State University, Oklahoma University, Stanford University, University of British Columbia, University of Chicago, University of Colorado, University of Illinois, University of Minnesota, University of Pennsylvania, University of Utah, Vanderbilt University, Yale University; and conference participants at the 2010 SITE and 2014 Safe Assets and the Macroeconomy Conference for helpful comments on this study and a predecessor paper. Nick della Copa, Ian Appel, and Jessica Jeffers provided excellent research assistance. Roberts gratefully acknowledges financial support from the Jacobs Levy Equity Management Center for Quantitative Financial Research. The views expressed herein are those of the authors and do not necessarily reflect the views of the National Bureau of Economic Research.

NBER working papers are circulated for discussion and comment purposes. They have not been peerreviewed or been subject to the review by the NBER Board of Directors that accompanies official NBER publications.

(C) 2014 by John Graham, Mark T. Leary, and Michael R. Roberts. All rights reserved. Short sections of text, not to exceed two paragraphs, may be quoted without explicit permission provided that full credit, including $\odot$ notice, is given to the source. 
How Does Government Borrowing Affect Corporate Financing and Investment?

John Graham, Mark T. Leary, and Michael R. Roberts

NBER Working Paper No. 20581

October 2014

JEL No. E22,E44,G20,G31,G32

\begin{abstract}
Using a novel dataset of accounting and market information that spans most publicly traded nonfinancial firms over the last century, we show that U.S. federal government debt issuance significantly affects corporate financial policies and balance sheets through its impact on investors' portfolio allocations and the relative pricing of different assets. Government debt is strongly negatively correlated with corporate debt and investment, but strongly positively correlated with corporate liquidity. These relations are more pronounced in larger, less risky firms whose debt is a closer substitute for Treasuries. Indeed, we find a strong negative relation between the BAA-AAA yield spread and government debt, highlighting the greater sensitivity of more highly rated credit to variation in the supply of Treasuries. The channel through which this effect operates is investors' portfolio decisions: domestic intermediaries actively substitute between lending to the federal government and the nonfinancial corporate sector. The relations between government debt and corporate policies, as well as the substitution between government and corporate debt by intermediaries, are stronger after 1970 when foreign demand increased competition for Treasury securities. In concert, our results suggest that large, financially healthy corporations act as liquidity providers by supplying relatively safe securities to investors when alternatives are in short supply, and that this financial strategy influences firms' capital structures and investment policies.
\end{abstract}

John Graham

Duke University

Fuqua School of Business

100 Fuqua Drive

Durham, NC 27708-0120

and NBER

john.graham@duke.edu

Mark T. Leary

Olin Business School

Washington University in St. Louis

Campus Box 1133, One Brookings Drive

St. Louis, MO 63130

and NBER

leary@wustl.edu

\author{
Michael R. Roberts \\ The Wharton School \\ University of Pennsylvania \\ 3620 Locust Walk, \#2319 \\ Philadelphia, PA 19104 \\ and NBER \\ mrrobert@wharton.upenn.edu
}


How does government borrowing affect the corporate sector? A large literature focuses on the prediction that an increase in government debt reduces investment by increasing the level of interest rates. ${ }^{1}$ However, when wealth effects are present in investors' portfolio decisions and asset markets are differentiated beyond money and capital, there are several implications for the corporate sector that have gone largely unexplored. In particular, fluctuations in the supply of government debt can alter the relative returns on assets in a manner that depends on the relative substitutability of different assets in investors' portfolios (Friedman (1978)). The prices of securities that are closer substitutes for government debt (e.g., corporate debt) react more strongly to variation in the supply of government debt than the price of securities that are poorer substitutes (e.g., corporate equity). This price variation can in turn alter firms' incentives to invest in different types of assets and issue different types of securities.

Recent evidence suggests such price effects are present in at least some segments of the capital markets. Krishnamurthy and Vissing-Jorgensen (2012) find that government borrowing affects Treasury-corporate yield spreads by altering the premium investors are willing to pay to hold safe and liquid assets. Baker, Greenwood, and Wurgler (2003) highlight predictability in corporate bond returns that Greenwood, Hansen, and Stein (2010) attribute to macro liquidity provision by firms in response to fluctuations in the supply of Treasuries across the yield curve. These findings complement earlier work by Friedman (1986) predicting that government debt issuances will increase the cost of corporate debt relative to equity. What is unclear at this point is whether variation in the supply of government debt, and the attendant price effects, ultimately impacts corporate policies.

The goal of this study is to shed light on this issue by investigating the relation between government borrowing and corporate capital structure, liquidity, and investment policies. We do so using a unique micro dataset containing accounting and market information for U.S. nonfinancial publicly traded firms over the last century. Our data enable us to exploit both timeseries and cross-sectional variation, the latter of which we show is critical for uncovering and understanding the link between government debt policy and corporate behavior.

We begin by documenting a significant and robust negative relation between government debt and corporate debt for nonfinancial firms in what we refer to as the unregulated sector, i.e.,

\footnotetext{
${ }^{1}$ See surveys by Elmendorf and Mankiw (1999) and Hubbard (2011).
} 
firms other than railroads, telecommunications, and utilities. ${ }^{2}$ A one standard deviation increase in government leverage (the ratio of government debt to total assets of the corporate sector) is associated with a one third standard deviation decrease in corporate leverage (the ratio of corporate debt to total assets). We find a similar significant, negative relation between the flow of government debt and the flow of corporate debt, with the results concentrated in long-term, as opposed to short-term, debt.

These findings are robust. The relation between corporate and government debt is economically and statistically significant controlling for firm characteristics and macroeconomic factors. Further, the relation is present in both levels and first differences, and between alternative measures of corporate debt (e.g., total debt, debt net of liquid assets) and government debt (e.g., debt held by the public, gross debt). Subsample analysis reveals that the negative relation between government and corporate debt policies is present throughout the last 100 years and is not attributable to the large government deficit of World War II or fiscal policy during recessions.

We find little evidence that firms substitute to alternative sources of funding, consistent with a large body of theoretical and empirical evidence highlighting segmented financial markets and corporate hedging demands. ${ }^{3}$ We find a statistically insignificant relation between government debt and corporate equity policies; however, we find a significantly positive and robust association between government debt and firms' holdings of cash and other short-term liquid assets, such as Treasuries. Thus, firms reduce their use of debt and increase their holdings of liquid assets in response to increases in government borrowing.

These findings are consistent with corporations increasing purchases and reducing sales of safe and liquid securities - relative to equity - in response to increases in government debt and the reduction in the price of these securities (Friedman (1986) and Krishnamurthy and VissingJorgensen (2012)). However, this analysis leaves open the possibility that variation in

\footnotetext{
${ }^{2}$ Our focus on unregulated firms is driven primarily by two considerations. First, the institutional environment and economic mechanisms responsible for financial and investment policy are fundamentally different across regulated and unregulated entities - a point emphasized throughout the capital structure literature (e.g., see Frank and Goyal (2008) for a review). Second, unregulated corporate assets represent the majority of nonfinancial corporate assets over the last 100 years and over $75 \%$ since 1950.

${ }^{3}$ See studies by Rubinstein (1973), Auerbach and King (1983), Bolton and Freixas (2000), Baker, Greenwood, and Wurgler (2003), Baker, Stein, and Wurgler (2003), Faulkender and Petersen (2005), Leary (2009), and Lemmon and Roberts (2010) for theoretical and empirical evidence of financial market segmentation. See studies by Acharya, Almeida, and Campello (2005) and Faulkender and Wang (2006) for evidence of hedging motives and the distinction between cash and debt.
} 
government debt policy is instead capturing latent or mismeasured corporate investment opportunities. An alternative interpretation of our findings is that the government issues debt in bad economic times during which investment opportunities are poor and, consequently, the demand for credit is low. The observable control variables narrow the scope for this alternative but do not eliminate it. In an effort to address this ambiguity and shed further light on precisely how government debt policy is influencing corporate behavior, we test for heterogeneity in the government debt-corporate policy relations, and investigate the mechanism and channel through which government debt affects corporate policies.

We find that the debt and leverage policies of larger, more credit-worthy firms are more sensitive to variation in government debt than are the policies of smaller, less creditworthy firms whose debt is a more distant substitute for Treasuries. Consistent with government debt influencing corporate policy, these findings are also more difficult to reconcile with the alternative of mismeasured investment opportunities because larger, more creditworthy firms exhibit financial and investment policies that are less pro-cyclical (Korajczyk and Levy (2003), Kashyap, Lamont and Stein (1994)). A useful by-product of this analysis is that it enables us to gauge the potential biases in our aggregate results from omitted variables by considering the differential effects of competing hypotheses. Our cross-sectional results reinforce our findings in the aggregate.

Building on the cross-sectional heterogeneity, we provide additional evidence of the price mechanism behind our results. Specifically, we find a robust and statistically significantly negative relation between the BAA-AAA corporate bond spread and the government debt-toGDP (and debt-to-asset) ratio. A one-percentage point increase in the debt-to-GDP ratio is associated with a $0.40 \%$ decrease in spread. This result not only reinforces the greater sensitivity of corporate policies to government debt among more credit-worthy firms, it also casts further doubt on the alternative hypothesis that our findings are driven by an omitted variable. If periods of high government indebtedness were proxies for bad economic times and poor investment opportunities, we would expect credit spreads to widen, not contract (Gilchrist and Zakrajsek (2010)).

To understand the channels through which government debt policy and corporate behavior are related, we examine the response of investors' portfolios to fluctuations in the supply of Treasuries. Domestic financial intermediaries - commercial banks, insurance 
companies, and state and local pension funds - are responsible for a significant portion of corporate lending. For each of these intermediaries, we find a strong negative association between government debt issuance and the fraction of assets allocated to corporate lending (e.g., loans and bonds): intermediaries' corporate loan-to-asset ratios fall between four and twelve basis points for each percentage point increase in government debt-to-assets. This finding is in contrast to the positive, but statistically weak, association between government debt and the fractions of bank and insurance company assets invested in agency bonds. Thus, financial intermediaries respond to increased government borrowing by increasing their holdings of government debt, marginally increasing their holdings of agency debt, and reducing their holdings of corporate debt.

Foreign investors, since 1970, have become a more important supplier of capital to both the federal government and domestic corporations. We find a significant negative coefficient in our leverage regressions on the interaction between government debt and foreign holdings of Treasuries relative to corporate bonds, implying that increases in foreign holdings of Treasuries amplify the negative association between corporate debt and government debt. We also find that the magnitude of the relations between government debt and corporate policies are generally larger after 1969 than before. Specifically, the magnitude of the relation between government debt and corporate debt more than doubles from the pre-1970 to the post-1969 eras. Likewise, the sensitivity of corporate net debt issuances to government net debt issuances increases in the latter era, though the estimate is statistically noisy.

These results suggest that that the supply of safe assets from nonfinancial corporations has become increasingly important over time for fulfilling excess demand due to variation in the supply of Treasuries. This interpretation fits well with the results in Krishnamurthy and VissingJorgensen (2013) and Gorton, Lewellen, and Metrick (2013), both of whom argue that there is excess demand by intermediaries for safe assets and this demand has been increasing over time. Thus, rather than relaxing a lending constraint on domestic intermediaries, the increase in foreign holdings of U.S. Treasuries appears to have lead to increased competition for safe assets making alternative sources of these assets more appealing.

Finally, turning to corporate investment, our findings mimic those for corporate debt policy. We find a significant negative association between government net debt issuances and corporate capital expenditures that is economically and statistically significant. A one standard 
deviation increase in the ratio of government debt to total assets of the corporate sector is associated with a one fifth standard deviation decrease in the ratio of capital expenditures to total assets. Like leverage and debt policy, the investment relation is robust to a host of controls, including government expenditures and macroeconomic factors, as well as firm characteristics such as the market-to-book ratio, cash flow, and lagged investment.

The investment results are also concentrated among larger, more financially healthy firms. We also find that the negative relation between government borrowing and investment increases in magnitude post-1969. In other words, when government borrowing increases the price of liquid assets relative to illiquid assets falls. This price decline reduces firms' opportunity cost of holding liquid assets and increases their cost of debt capital. Firms respond by reducing their purchases of illiquid assets (investment) and sales of liquid assets (debt), and increasing their holdings of liquid assets (e.g., Treasuries). Thus, another message of our study is that large, safe nonfinancial corporations act as liquidity providers in credit markets - as suggested by Greenwood, Hanson, and Stein (2010) - and that this liquidity provision affects not only the composition of corporate liabilities but also real economic outcomes.

The motivation for our study dates back to early work by Blinder and Solow (1973), Tobin and Buiter (1976) and Friedman (1978) who first investigated the portfolio crowding out emphasized by Friedman (1972). More recently, our study is related to work by Greenwood, Hanson, and Stein (2010) and Badoer and James (2013), both of whom focus on the implications of the maturity structure of government borrowing for the maturity structure of corporate liabilities.

Though not the focus of their study, Graham, Leary, and Roberts (2013) document a negative correlation between corporate debt and government debt. Our study goes beyond their findings by investigating the meaning of this relation, linking it to corporate liquidity and investment, and providing evidence on the mechanism (prices) and the channel (domestic intermediaries and foreign investors) behind the quantity relations. Complementing our work is recent evidence in Krishnamurthy and Vissing-Jorgensen (2014) showing that the supply of short term Treasuries is negatively correlated with the supply of short-term debt issued by the financial sector. Thus, while the financial sector helps fill excess demand for safe short-term securities, the nonfinancial corporate sector helps fill excess demand for safe long-term securities. 
More broadly, our study is related to a large macroeconomic literature investigating government crowding out via borrowing (e.g., Elmendorf and Mankiw (1998) and Hubbard (2011)). Our results are clearly suggestive of a crowding out effect, though data limitations - our emphasis on the unregulated sector of the economy - limit our conclusions about aggregate investment.

The remainder of the paper proceeds as follows. Section I introduces the data and presents summary statistics. Section II discusses the theoretical motivation for why government debt might affect the corporate sector. We also outline our empirical framework and highlight the identification challenges. Section III presents results relating government debt to aggregate corporate financial structure and liquid asset holdings. Section IV investigates how the relationship between government debt and corporate policies varies in the cross-section of firms. Section $\mathrm{V}$ presents evidence on the price mechanism by relating government debt to crosssectional differences in the debt cost of capital faced by corporations. Section VI examines the portfolio behavior of investors holding government and corporate debt - the channel linking the two sectors. Section VII examines the implications for corporate investment and Section VIII concludes.

\section{Data and Summary Statistics}

The sample of firms includes all firms listed in the Center for Research in Security Prices (CRSP) monthly stock files. This sample includes all firms listed on the New York Stock Exchange (NYSE) since 1925, all firms listed on the American Stock Exchange (AMEX) since 1962, and all firms listed on the NASDAQ since 1972. For these firms, stock market data comes from CRSP. Balance sheet and income statement information are obtained from two sources: Standard and Poor's (S\&P) Compustat database and data hand-collected from Moody's Industrial and Railroad manuals by Graham, Leary, and Roberts (2014). We exclude financial firms from all of our analysis. The end result is an unbalanced firm-year panel beginning in 1920 and ending in 2012.

We distinguish between two sectors of the economy that we loosely refer to as regulated (utilities, telecommunications, and railroads) and unregulated (all other nonfinancial industries) because of different institutional environments. We recognize that regulatory status is dynamic, 
heterogeneous, and extends beyond our classification (e.g., airlines). Thus, we emphasize that these are merely labels to identify a division in our data that acknowledges the different mechanisms determining financial policy across these sectors, and that are consistent with previous research on corporate financial policy (e.g., Graham and Leary (2011)). We focus our attention on the unregulated sector for reasons mentioned in footnote 2 . We also note that the unregulated sector comprises over 50\% of the economy's assets over the entire sample period, and over $75 \%$ since 1950, as shown in Figure 1.

We supplement these data with a number of macroeconomic time-series. Together, we form two samples based on the corporate and macroeconomic data. The first is an annual timeseries containing aggregate corporate measures and macroeconomic factors. The aggregate corporate measures are constructed by summing across firms each year. For ratios, we sum separately the numerator and denominator before taking the ratio. The second sample is a firmyear panel. Details regarding variable construction and data sources are presented in Appendix A.

Table I presents summary statistics for the primary variables used in our analysis. Panel A presents aggregate time-series statistics, Panel B panel data statistics. In the panel, we winsorize each ratio at the upper and lower one percentiles to address possible data-coding errors and mitigate the influence of outliers. Consistent with most capital structure studies, we scale variables by the book value of assets. This also ensures a meaningful interpretation of our corporate measures that are based on a subset of the corporate sector - unregulated firms discussed above. We examine alternative scale factors, such as GDP, in our analysis below.

Corporate debt is defined as all interest bearing debt. Government debt is defined as federal debt held by the public, which excludes intergovernmental holdings (e.g., by the social security administration) but includes holdings by the monetary authority. We examine alternative definitions, e.g., gross debt and debt net of the Federal Reserve's holdings, below. We focus on federal debt because it represents the majority of total government debt and is responsible for most of the latter's variation over time. ${ }^{4}$

\section{Theoretical Motivation and Identification Strategy}

\footnotetext{
${ }^{4}$ See Figure 1 in Appendix A of Graham, Leary, and Roberts (2013).
} 
Economic theory provides several reasons for government borrowing to affect corporate policies. ${ }^{5}$ A traditional view (Elmendorf and Mankiw (1999)) of budget deficits is that they increase aggregate demand but bring about a rise in interest rates and corresponding reduction in investment. However, as illustrated by Friedman (1978), when wealth effects are present in investors' portfolio decisions, government borrowing will alter the relative returns of assets in a manner that depends on the substitutability of the assets.

Intuitively, investors absorb an increase in the supply of Treasuries by holding a larger fraction of their wealth in Treasuries. By necessity, they must hold less of other assets. If investors are unwilling to freely substitute between different securities (i.e., capital markets are not perfect), a change in the structure of market expected returns is required to restore equilibrium. In particular, the yields on close substitutes to the security issued by the government are expected to rise in tandem with Treasury yields. For other financing instruments, such as risky debt or equity, the effect depends on the relative substitutabilities of different securities in investors' portfolios.

Friedman (1986) uses asset demands derived from a portfolio optimization problem to estimate the impact of a change in Treasury supply on debt and equity yields. While the magnitudes of the estimates are sensitive to assumptions about investor preferences and the covariance structure of asset returns, they all suggest an increase in the cost of debt relative to the cost of equity. Thus, debt financing should respond inversely to government borrowing, all else equal. ${ }^{6}$

Other theories appeal to various market frictions that result in debt and equity securities being imperfect substitutes in investors' portfolios. For example, McDonald (1983) builds on the ideas in Miller (1977) to examine the impact of government debt issuance when investors differ in their tax status and there are limits to arbitrage. High tax investors have a preference to hold equity due to the differential personal tax treatment. An increase in the supply of taxable bonds causes an increase in the yield on corporate bonds to compensate high tax rate investors.

\footnotetext{
${ }^{5}$ The Riccardian view of budget deficits (Barro (1974)) is one of indifference and, as such, provides little motivation for our study unless one believes that corporate financial policy is value neutral. In other words, a link between government borrowing and corporate financial policy can exist under Riccardian equivalence, assuming corporate financial policy is not affecting real economic outcomes, such as investment. Given the mass of evidence suggesting otherwise (e.g., Stein (2003)), we focus our discussion on theories linking government borrowing to corporate policies via market imperfections.

${ }^{6}$ Greenwood, Hansen, and Stein (2010) similarly argue that the relative price of corporate debt of different maturities is sensitive to the maturity of debt issued by the government.
} 
This rise in the after-tax cost of debt relative to equity leads to a reduction in corporate borrowing in response to the increase in government borrowing. ${ }^{7}$

Taggart (1985) undertakes a similar investigation but assumes that investors differ in either their risk aversion or optimism and face transaction costs that prevent them from freely replicating the return streams of one security with combinations of others. As in McDonald (1983), increases in the supply of government debt supply must be absorbed by investors who are less willing to hold it, forcing an increase in corporate debt yields and a resulting decline in corporate debt issuance.

While these theories all predict an inverse relation between government and corporate borrowing, the model in Krishnamurthy and Vissing-Jorgensen (2012) (hereafter KVJ) has implications for the holdings of liquid assets by corporations. KVJ show that yields on Treasury securities contain a "convenience" component comprised of high liquidity and safety that cannot be replicated by investors. Further, KVJ show that increases in the Treasury supply reduce this liquidity premium, or opportunity cost of holding liquid assets. The literature on corporate cash holdings argues that this liquidity premium, or opportunity cost, is one of the primary costs of holding liquid assets. Thus, firms should be willing to hold more treasuries, and other close substitutes, when the government borrows more and the opportunity cost of holding liquid assets falls.

Finally, Friedman (1978) points out that the portfolio rebalancing induced by an increased supply of Treasuries can also have subtle implications for corporate investment. A key determinant of corporate investment is the required rate of return on corporate securities. If corporate securities are not close substitutes for Treasuries, excess supply in the government bond market can be cleared either by an increase in Treasury yields or a decrease in yields on alternatives such as riskier corporate debt and equity. The lower the substitutability between Treasuries and these corporate alternatives, the more likely the corporate cost of capital will fall in response to an increase in the supply of Treasuries. In short, the impact on corporate funding costs may be smaller or even in the opposite direction than the effect on yields of the securities issued by the government.

On the other hand, in the presence of market frictions, the capital structure effects discussed previously may negatively impact investment, reinforcing the traditional crowding out

\footnotetext{
${ }^{7}$ See Benninga and Talmor (1988) for a similar treatment in a general equilibrium context.
} 
mechanism. Ultimately, the effect on corporate investment decisions is theoretically ambiguous. However, because the securities of safer firms are closer substitutes for Treasuries than those of riskier firms, we expect safer firms' investment policies to be most sensitive to changes in government debt issuance.

To summarize, existing theories produce the following testable implications on which we focus. First, government and corporate debt are inversely related. Second, government debt and corporate liquidity are positively related. Third, as emphasized by Friedman (1986), yields on securities that are closer substitutes to Treasuries are expected to increase relative to yields on more distant substitutes following an increase in government debt issuance. More concretely, the spread between yields on risky and safe borrowers will decrease following a rise in Treasury issuance. Further, the financial policies of safer borrowers will be more sensitive to government deficit financing than those of riskier borrowers. Finally, while the impact of government borrowing on investment is theoretically ambiguous, the investment policies of safer borrowers should be more sensitive to deficit financing than those of riskier borrowers.

\section{II.A Empirical Strategy and Identification Challenges}

In light of the preceding discussion, our empirical approach is to estimate linear asset demand equations. To fix ideas, consider our model of corporate debt:

$$
\frac{Q_{t}^{C}}{A_{t}}=\alpha+\beta \frac{Q_{t}^{G}}{A_{t}}+\Gamma X_{t}+\varepsilon_{t},
$$

where $Q_{t}^{C}$ is the quantity of corporate debt, $Q_{t}^{G}$ is the quantity of government debt, $A_{t}$ is the book value of total assets, $X_{t}$ is a vector of control variables, and $\varepsilon_{t}$ is a possibly serially correlated error term. To address this possibility, we estimate Newey-West standard errors with two lags, a practice that we repeat for all aggregate time-series analysis. To address concerns over trends during our sample period (Granger and Newbold (1974)), we incorporate a linear trend in the level specification and separately estimate equation (1) after first differencing the dependent and independent variables.

We address confounding forces with a set of observable, contemporaneous controls motivated by the theoretical discussion above and existing empirical evidence. Quantities are normalized by the book value of assets to address scale differences and maintain consistency 
with our leverage measures. We address the issue of government demand by including a measure of federal expenditures. This ensures that any identifying variation is driven by the government's choice of financing - debt versus taxes. We include the market-to-book asset ratio and real GDP growth to capture corporate investment opportunities. The yield spread between a BAA-rated corporate bond and the ten-year Treasury bond captures variation in the risk premia on corporate debt. ${ }^{8}$ The return on a three-month Treasury bill reflects the level of interest rates and the financing and investment environment. Inflation is included because corporate debt is measured in nominal terms. We also include the return on assets, EBIT / Assets, and a measure of asset intangibility - two important empirical determinants in the capital structure literature (Rajan and Zingales (1995) and Frank and Goyal (2008)).

While correlating government policy with corporate policies via equation (1) is straightforward given our data, interpreting any correlations is difficult. The ideal experiment would randomly shock the supply of Treasuries, holding fixed the supply of corporate debt, the investment opportunities of the corporate sector, and government investment. Lacking such a shock, any correlation between government debt and corporate behavior may still be consistent with several alternatives. For example, a negative relation between government debt and corporate debt (and investment) could reflect the econometrician's inability to adequately hold fixed corporate investment opportunities. In this interpretation, the government issues debt in bad times when investment opportunities are poor and firms' demand for credit is low because their desire to invest is low. Alternatively, optimal capital structure may fluctuate over the business cycle in a way that is correlated with government borrowing. In other words, variation in $Q_{t}^{G}$ may capture variation in latent or mismeasured investment opportunities or other determinants of financial policies.

We take several approaches to address this concern. The first is to control for confounding variation by way of observables, $X$. Recognizing the limitations of this approach, we also exploit heterogeneity in the estimated effect. In particular, we allow the parameter on the government debt variable, $\beta$, to vary over time and cross-sectionally with observables in an attempt to rule out alternative explanations. Third, we investigate the price mechanism that

\footnotetext{
${ }^{8}$ There is concern that in addition to capturing macroeconomic conditions, the credit spread may capture part of the price channel through which variation in the Treasury supply is transmitted onto corporate policies. Our approach to including it is therefore a conservative one whose robustness is addressed below.
} 
transmits government debt policy onto corporate policies. Finally, we investigate the channel through which the quantity relation operates, namely, investors' portfolio decisions. While none of these empirical strategies provide a clear source of exogenous variation in $Q_{t}^{G}$, in concert they can provide evidence that significantly limits the scope for alternative interpretations.

\section{The Relation Between Government Debt and Corporate Financial Policies}

\section{III.A Corporate Leverage}

Panel A of Figure 2 illustrates the relation between corporate and government leverage ratios. During the last century, government debt experienced several notable transitions beginning with a dramatic expansion to fund World War II. From its peak of 109\% of GDP in 1946, government debt as a share of income fell steadily until 1972 when it leveled off at approximately $25 \%$ of GDP. The 1980s saw a renewed increase in public sector leverage that persisted until the mid-1990s. In 2008, public debt-to-GDP began another steep increase in response to the most recent recession and financial crisis.

Turning to corporate leverage, a negative relation with government leverage is apparent, over the first half of our sample period. As government leverage increased sharply from 1917 to 1945, corporate leverage experienced a less severe but nonetheless significant decline from $13 \%$ to $6.5 \%$ over this same period. From 1945 to 1970, as government debt fell, corporate leverage increased more than threefold to $27 \%$. After little change during the 1970s, corporate debt increased sharply in the mid-1980s in conjunction with the leveraged buyout boom (Kaplan and Stromberg (2009)) before trending downward over the next thirty years. ${ }^{9}$ As shown in Graham, Leary, and Roberts (2013), the other measures of leverage examined in Table I exhibit similar patterns.

Panel A of Table II presents ordinary least squares (OLS) regression results for several specifications of equation (1). The estimates reveal the following inferences. First, government leverage and corporate leverage are strongly negatively related. This relation is robust to the inclusion of both macroeconomic and firm characteristic control variables. This relation is found

\footnotetext{
${ }^{9}$ Our accounting data include limited information on privately held firms that rely on publicly traded debt, or that went public in the subsequent year as both require filings with the SEC.
} 
in both levels and first differences, though there is an attenuation in moving to the difference specifications.

Several other estimates are worth mentioning. Real GDP growth exhibits a clear negative correlation with corporate leverage, consistent with previous research emphasizing countercyclical leverage among nonfinancial firms (e.g., Korajczyk and Levy (2003)). The yield spread is insignificant in the levels specification, but significantly positive in the difference specification implying that as the rate of change in the yield spread increases the rate of change in leverage ratios tends to increase. Interestingly, government expenditure is uncorrelated with corporate leverage, once firm characteristics and other macroeconomic indicators are held constant. Finally, we see a strong negative association between profitability and leverage, consistent with prior evidence (e.g., Frank and Goyal (2009)) and the corporate preference to use internal equity for financing.

To gauge the economic significance of these estimates, we scale them by the ratio of the standard deviation of the independent variable to that for the dependent variable. The estimate in Column (6) of Table II implies that a one standard deviation increase in government leverage is associated with a one third standard deviation decrease in corporate leverage. This represents the largest marginal effect, with profitability and real GDP growth second and third, respectively.

Panel B of Table II presents the results of a host of additional robustness tests. The baseline model for this analysis is the same as that presented in column (6) of Panel A - a regression of corporate leverage on government leverage, firm characteristics, and macroeconomic factors estimated in first difference form. We modify this baseline specification in a variety of ways, as indicated by each row. The number in each row corresponds to the coefficient estimate on government leverage, below which is the corresponding t-statistic in parentheses.

We explore the effect of alternative measures of corporate leverage, our dependent variable, on the sensitivity to government leverage in the first three rows. The first row defines corporate leverage as the ratio of "net debt" to assets, where net debt is defined as debt minus liquid assets (i.e., cash and short-term investments). The marginal effect of government leverage on this leverage measure is significantly larger than that found in Panel A. As we discuss in the next section, this is because of the positive correlation between corporations' liquid assets and government leverage. The second and third rows replace the numerator of our leverage measure 
with long-term debt and short-term debt, respectively. We see similar negative associations for both measures in the first difference specifications. The magnitude is somewhat smaller than in Panel A reflecting the weak correlation between long- and short-term debt policies. ${ }^{10}$

The fourth row shows that the relation between corporate and government leverage persists after including a host of additional control variables that are plausibly correlated with either investment opportunities or the supply of corporate debt. These variables include: a debt tax incentive defined as the difference in the corporate and personal income tax rates divided by one minus the personal income tax rate (e.g., Taggart (1985)), the real price of oil, the unemployment rate, the growth in the money supply, the growth in real assets of corporations, one-period ahead real GDP growth, a recession indicator variable, and the yield spread on the ten-year Treasury Bond and three month Treasury Bill.

In untabulated analysis, we investigate the effect of alternative measures of federal debt. In particular, we examine gross federal debt and federal debt held by the public net of any holdings by the monetary authority. Coefficient estimates on these alternative measures are similar in magnitude (and sign) to those found with our primary measure of government borrowing.

The result in the fifth row shows that scaling corporate and government debt measures by GDP, instead of assets, has a small effect on the sensitivity between the two.

We examine the relation during different subperiods in rows six through nine. With less than 90 observations, statistical power is limited. Nonetheless, (lack of) variation in the magnitude of the coefficient on government leverage can still be informative. Excluding the years during and just after World War II (1942-1955) leads to a significant increase in the magnitude of the estimate. This result shows that results are not an artifact of the extremely high government debt levels surrounding the War. When we split the sample, both halves reveal a statistically significant relation. However, the estimate from the second half of our sample period is more than three times the magnitude of the estimate from the first half. We further explore this difference below. Row (9) shows that the sensitivity is not just occurring during recession years, defined as years containing two or more quarters identified by the NBER as contractionary.

\footnotetext{
${ }^{10}$ We note that balance sheet measures of short-term debt include both debt securities with maturities of less than one year and debt securities with maturities in excess of one year but that are maturing within a year.
} 
The last two rows examine alternative samples aimed at addressing concerns about sample turnover. The average annual entry rate is $7.9 \%$ and is driven by initial public offerings, reverse buyouts, and broadening sample coverage. The average annual exit rate is $5.6 \%$ and is driven by bankruptcies, delistings, mergers, acquisitions, and buyouts. Row (10) defines the sample as the 500 largest firms each year. The turnover in this group is less than $2 \%$ per annum. Row (11) just examines NYSE-listed firms facing a similarly low turnover. The results are almost identical to that found in column (6) in Panel A, suggesting that sample composition effects are not behind our results.

\section{III.B Corporate Financial Flows}

We now investigate the relation between the flow of government debt and the sources of funds for firms with the following regression:

$$
\frac{Q_{t}^{C_{j}}-Q_{t-1}^{C_{j}}}{A_{t-1}}=\alpha+\beta \frac{Q_{t}^{G}-Q_{t-1}^{G}}{A_{t-1}}+\Gamma X_{t}+\varepsilon_{t},
$$

where $Q_{t}^{C_{j}}$ is the quantity of corporate security $j$ - total debt, long-term debt, short-term debt, and equity. The control variables are the same as those found in the leverage specification, equation (1). All (economic) stock and price control variables are lagged one period. Flow control variables are contemporaneous with the dependent variable.

Table III presents the estimation results. As a fraction of assets, corporate net debt issuances are negatively associated with government net debt issuance, but the coefficient estimate is statistically insignificant. Columns (2) and (3) shed light on this result. We see that the total debt issuances variable conflates two distinct forces: long-term debt issuances and shortterm debt issuances. Column (2) shows a slightly larger (in magnitude) and statistically significant coefficient estimate in the long-term debt regression. By contrast, column (3) shows an economically small and insignificantly positive coefficient for short-term debt. Thus, the financing substitution effect appears to be concentrated in long-term debt, consistent with the findings in James and Badoer (2013).

By contrast, the estimate for net equity issuances is positive (column (4)) and statistically insignificant, but of similar magnitude to that in the long-term debt specification. The results also reveal that equity market conditions, as measured by stock market returns and the market-to- 
book ratio, are the most important determinants of net equity issuances. In sum, government borrowing appears to affect corporate financing and capital structure largely through the longterm debt decisions of firms.

\section{III.C Liquid Assets}

Because the literature studying corporate liquidity has closely followed the capital structure literature (e.g., Opler et al. (2001)), our model specification for corporate liquidity follows closely the debt specification in equation (1). The dependent variable is the ratio of corporate cash and short-term investments to total assets. Because of the precautionary motive for holding liquid assets, we also include a measure of earnings volatility as a control variable.

Panel B of Figure 2 illustrates the relation between corporate liquidity and government leverage ratios. At a low frequency, the similarity in the evolution of government leverage and corporate liquidity is stark. Interestingly, recent levels of liquidity often described as "high" (Bates, Kahle, and Stulz (2009)), are in fact modest by historical standards. Corporate liquidity was nearly $25 \%$ as a fraction of total assets at the end of World War II, before beginning a steep and protracted decline until 1970.

In Table IV, we examine the effect of government borrowing on corporate liquidity policy. Specifically, we regress the ratio of cash and short-term investments to total assets on the ratio of government debt-to-assets and control variables discussed earlier. Columns (1) through (3) present estimates based on a levels specification, columns (4) through (6) present estimates based on a first-difference specification.

We note a statistically and economically large positive association between corporate liquidity policy and government borrowing. Using the point estimate from column (6), a one standard deviation increase in the stock government debt is associated with a one standard deviation increase in the stock of liquid assets held by corporations. As a percentage of assets, the marginal effect of government leverage on corporate liquidity is similar in magnitude to that on corporate leverage.

To summarize, increases in government borrowing are associated with a reduction in long-term debt issuances by firms and an increase in firms' liquid asset holdings, which lead to 
lower corporate leverage. While suggestive, the remainder of our study seeks to better understand these relations and the mechanisms behind them.

\section{Financing Effects in the Cross-Section}

In this section we buttress the evidence above by exploiting cross-sectional variation provided by our panel data. In particular, we ask: which firms' financial policies are more (less) sensitive to variation in government debt? In classifying firms, we focus on financial health or credit-worthiness because the debt of more credit-worthy firms is a closer substitute than that of less credit-worthy firms (Friedman (1986)). Thus, the relation between corporate policies and government debt should be stronger for more credit-worthy firms.

We use three proxies to capture a firm's credit-worthiness: firm size, the Hadlock-Pierce (HP) index of financial constraints, and an estimated probability of default based on the model of Merton (1974) (see Bharath and Shumway (2008)). Our choice of these proxies is motivated by a large literature in finance identifying these metrics as robust measures of financial health and credit-worthiness. ${ }^{11}$ The choice is also motivated by data limitations; credit ratings are available only for a small subset of firms and only since the 1980s. Each year, we classify firms into four groups based on quartiles for each proxy. To maximize power, we restrict the sample to the lower and upper quartiles. For example, small firms are defined as those firms falling in the lowest quartile of the distribution of assets, while large firms are those firms falling in the highest quartile.

We then run the following fully interacted panel regression:

$$
\begin{aligned}
y_{i t} & =\alpha+\beta_{1} g_{t} \times I\left(\text { low }_{i t}\right)+\beta_{2} g_{t} \times I\left(\text { high }_{i t}\right)+\Gamma_{1} X_{i t} \times I\left(\text { low }_{i t}\right) \\
& +\Gamma_{2} X_{i t} \times I\left(\text { high }_{i t}\right)+\mu_{i} \times I\left(\text { low }_{i t}\right)+\mu_{i} \times I\left(\text { high }_{i t}\right)+\varepsilon_{i t}
\end{aligned}
$$

where $y_{i t}$ is the corporate outcome variable (leverage or long-term debt issuance), $g_{t}$ is the government debt variable (either net debt issuance scaled by lagged assets or the level of debt scaled by contemporaneous assets), and $I\left(l o w_{i t}\right)$ and $I\left(h i g h_{i t}\right)$ are indicators equal to one if the proxy for firm $i$ in year $t$ is in the low or high strata. The standard errors are clustered by year

\footnotetext{
${ }^{11}$ For example, Shivdasani and Zenner (2005) show that firm size is the most important determinant of credit ratings; Hadlock and Pierce (2010) demonstrate their index based on firm size and age captures financial constraints well; Bharath and Shumway (2008) show that their naïve estimator predicts default as well, if not better than, other measures.
} 
because the critical identifying variation behind the parameters of interest, $\beta_{1}$ and $\beta_{2}$, is in the time series. The control variables - not reported - are identical to those found in in column (6) of Panel A, Table II (leverage) and column (2) of Table III (financing flows).

Equation (5) is akin to running a firm fixed effect regression separately on each subsample defined by the lower and upper quartiles of the credit-risk proxy distribution. However, equation (5) provides for a simple t-test of the difference between $\beta_{1}$ and $\beta_{2}$.

The estimation results are presented in Table V, with t-statistics in parentheses and firmyear observation counts (Obs). Columns (1) and (2) present the results using firm size to identify the strata. The first set of results shows that the coefficient estimate in the regression of corporate leverage on government leverage (and control variables) equals -0.062 when estimated on the subsample of small firms, and -0.117 when estimated on the subsample of large firms. In other words, the leverage of large firms is nearly twice as sensitive to government leverage than that of small firms. Column (3) shows that this difference, -0.056 , is statistically different from zero at the $1 \%$ level. Moving down columns (1) through (3), we see that large firms' long-term debt policies also are more sensitive to government net debt issuances than those of small firms.

When we look at alternative proxies for financial health, we find similar results. While some of the differences are statistically noisy, less financially constrained firms and firms with a lower likelihood of default have financial policies that are uniformly more sensitive to government borrowing than those of their more constrained and riskier counterparts. Overall, our cross-sectional results confirm the implications of Friedman (1986) by showing that firms whose debt is a closer substitute for Treasuries respond more to variation in the supply of Treasuries.

An important by-product of these findings is their ability to further mitigate identification concerns. Previous work by Korajczyk and Levy (2003) suggests that financial constraints have an asymmetric effect on firms' financial policies over the business cycle. In particular, they find that financing constraints are more binding in bad times, implying that more constrained firms should experience sharper declines in credit and investment in economic downturns than their unconstrained counterparts. If variation in government debt is capturing variation in the broader economic environment and influencing our estimate, then we would expect to see more financially constrained firms' policies more responsive to government debt than the policies of less financially constrained firms. 
Likewise, this analysis can help alleviate concerns about contemporaneous shifts in the supply curve of corporate debt due to variation in its determinants, such as expected default costs, agency costs or information asymmetry. Specifically, financially constrained firms are characterized as such precisely because they face greater frictions. We would expect these frictions, and the constraints they engender, to be exacerbated in bad times. For example, expected default costs are higher in bad times when secondary asset markets are depressed and less liquid, and the resulting likelihood of default is greater. However, if variation in government debt is just capturing variation in these frictions, this would suggest the financial policies of constrained firms should be more sensitive to government borrowing than those of unconstrained firms, opposite of our findings.

Finally, this analysis helps us gauge the potential biases from omitted variables by considering the differential effects of competing hypotheses. Under the hypothesis that government borrowing is crowding out close substitutes in investors' portfolios, so-called portfolio crowding out (Friedman (1978)), we should see little if any relation between government borrowing and the policies of smaller, less creditworthy firms. Under the traditional transactions crowding-out hypothesis there is no reason to expect a differential response by firms to the governments' fiscal policy because an increase in the level of interest rates will increase the cost of capital uniformly for firms. Finally, if government borrowing is simply proxying for latent investment opportunities, the effect on corporate debt policy is likely to be larger for smaller, less credit-worthy firms because financing frictions will amplify the effect of a deterioration in economic conditions. Together, these hypotheses suggest that the estimated differences across strata provide a plausible lower bound on the true relation.

Intuitively, the differential parameter estimates across strata correspond to a treatmentcontrol comparison in which large, credit-worthy firms act as the treatment group and small, less credit-worthy firms act as the control. Of course, assignment to these groups is non-random; however, the discussion above suggests that selection effects will work to attenuate the estimated differences. Taking the average differential across the proxies produces estimates equal to -0.049 for leverage and -0.058 for long-term debt issuances. Compared to their aggregate counterparts -0.039 (column (6) of Table II) and -0.047 (column (2) of Table III) -the estimates are of roughly similar magnitudes. 


\section{The Mechanism: Prices}

For government debt to affect corporate financial policy and investment, the effect would likely occur via the cost of capital. While other mechanisms exist to clear credit markets, such as quantity rationing (e.g., Stiglitz and Weiss (1983)), these alternatives are less relevant for our findings, which are concentrated among larger, more financially secure firms. In other words, high credit quality firms are less likely to be quantity-rationed from credit markets. Rather, they are responding to price changes induced by variation in the supply of Treasuries.

We investigate this hypothesis by estimating

$$
y_{t}^{L}-y_{t}^{H}=\alpha+\beta \ln \left(\frac{Q_{t}^{G}}{A_{t}}\right)+\Gamma X_{t}+\varepsilon_{t},
$$

where $y_{t}^{L}$ and $y_{t}^{H}$ represent the yield on low and high credit-quality corporate debt, respectively. We use the BAA-AAA corporate bond yield spread to proxy for this difference. Our control variables incorporate proxies for default risk (equity volatility, corporate profitability, and an estimated default probability) and the state of the economy (the slope of the yield curve and real GDP growth). This model follows closely that of Krishnamurthy and Vissing-Jorgensen (2012).

Theory and our cross-sectional results predict that this spread is negatively correlated to government borrowing since the prices of more credit-worthy debt should respond more to variation in the supply of Treasuries than the prices of less credit-worthy debt. The results in Table VI confirm this prediction by showing a highly statistically significant and robust negative association between the BAA-AAA spread and government leverage.

In addition to complementing the preceding quantity results, these findings cast further doubt on the alternative hypothesis that government debt is proxying for economic conditions in our empirical specifications. If this were true, one would expect a positive relation between government leverage and a BAA-AAA credit spread, which tends to widen in bad times (e.g., Gilchrist and Zakrajsek (2010)), i.e., periods with high government debt.

\section{The Channel: Investors}

\section{VI.A Domestic Investors}


To understand the channel through which government debt influences corporate policy, we turn to an investigation of investors, and in particular investors holding a significant fraction of corporate debt and Treasuries.

Figure 3 presents the distribution of corporate bond holdings across investor types, as reported in the U.S. Flow of Funds. Domestic financial institutions have historically held a large majority of corporate bonds. Insurance companies have been the largest investors, life insurers in particular. State and local pensions also hold a significant fraction of corporate bonds. Since 1970, this distribution has experienced two significant changes. The first began in the 1970s with the increase in foreign holdings. The second began in the 1980s with the increase in mutual fund holdings and, since the early '90s, "other," which is comprised primarily of securities brokers and dealers and funding corporations associated with financial stabilization.

Figure 3 highlights that a linkage between government debt and the policies of the nonfinancial corporate sector would likely be found in the portfolios of financial intermediaries. It also suggests that there may be variation in these relations over time, as the ownership structure has changed substantially since 1970 .

Figure 4 examines the asset allocations of these intermediaries over time from the Flow of Funds. To ease the presentation, we focus on the allocation across credit market instruments. Panels A, B, and C present the results for commercial banks, insurance companies, and state and local pension funds, respectively. Several results stand out. First, Treasuries as a share of intermediaries' portfolios declined dramatically between 1945 and 1970 as the government gradually retired outstanding bonds used to finance World War II. Second, there appears to be a negative association between Treasury and corporate debt holdings, though the strength is visually unclear.

We examine the portfolio allocation behavior of these institutions by estimating the following regression:

$$
\frac{A_{t}^{i}}{F A_{t}}=\alpha+\beta \frac{Q_{t}^{G}}{A_{t}}+\Gamma X_{t}+\varepsilon_{t}
$$

where $A_{t}^{i}$ is the quantity of asset $i$ on the balance sheet of the intermediary, and $F A_{t}$ is the total quantity of financial assets held by the intermediary. All other variables are defined as before, as is possible serial correlation of the errors. We employ the same control variables as in our leverage specification (Column (6) of Table II) and estimate equation (5) in first differences. 
Table VII presents the results. To ease the presentation, we report only the estimated coefficient on the government debt variable and corresponding t-statistic in parentheses. Each panel presents estimation results for a different dependent variable, namely, a different credit market instrument on the asset side of the intermediary's balance sheet. For example, the top panel presents results when $A_{t}^{i}$ is corporate debt. For commercial banks, corporate debt consists of C\&I loans and corporate bonds, for insurance companies this asset consists of corporate bonds and private placements, and for state and local pensions this asset consists of corporate bonds and commercial paper. Odd numbered columns present the estimates from a univariate regression, even numbered from a multivariate regression containing the controls mentioned above.

For all intermediaries, increases in government borrowing are met with decreases in corporate lending, though the multivariate pension fund result is statistically weak. In contrast, the second panel shows the opposite effect on intermediary Treasury holdings, which increase with increases in the supply of Treasuries. Thus, intermediaries substitute between lending to corporations and lending to the federal government.

The third panel shows that this substitution is not mechanical. The holdings of agency bonds, at least among banks and insurers, are positively associated with government debt but none of the estimates are statistically significant. Thus, intermediaries absorb increases in the supply of Treasuries by reducing lending to the corporate sector.

\section{VI.B Foreign Investors}

Figure 5 shows that foreign ownership of US debt changed dramatically during the $20^{\text {th }}$ century. In particular, foreign ownership of US Treasuries increased sharply in 1971 when the US decided to move off the gold standard and let the dollar float. Foreign ownership hovered around $17 \%$ for the next 24 years, then sharp rises in foreign savings propelled foreign holdings of US Treasuries to over $50 \%$ by 2008 . The figure also shows a contemporaneous rise in foreign holdings of corporate debt, though at a more moderate rate.

The question we ask in this section is what, if any, effect did this credit market integration have on the behavior of domestic intermediaries and, ultimately, on the relation between government debt and corporate behavior? There are several potential answers. For 
example, increased demand by foreign investors may ease lending constraints on domestic intermediaries who no longer have to absorb Treasury supply variations. This easing would free up the capital of domestic intermediaries to lend to the corporate sector. If true, then the growth of foreign holdings of Treasuries should attenuate any relation between government borrowing and the corporate sector.

Alternatively, increasing demand by foreign investors may reflect increasing competition for safe assets (Gorton et al., 2012), which intermediaries prefer to hold because of their advantage as a source of collateral or because of their role in easing regulatory constraints (e.g., risk-based capital requirements). In this case, as discussed by Bernanke et al. (2011), the increase in foreign demand for safe assets will induce intermediaries to "demand more of assets considered substitutable with Treasuries and Agencies, putting downward pressure on interest rates on these private assets as well." (p. 7). That is, foreign competition to hold Treasuries creates excess demand for safe assets, which is filled in part with safe corporate debt. In this case, an increase in Treasury issuance reduces excess demand for safe assets among these intermediaries, reducing their demand for corporate bonds. Under this alternative, then, increasing foreign demand for Treasuries can heighten the sensitivity of corporate lending to Treasury supply. Any foreign demand for corporate debt will mute this effect.

To investigate these hypotheses, we add two variables to the leverage specification in equation (1). The first is the foreign holdings wedge defined as the difference between foreign holdings of Treasuries and foreign holdings of corporate bonds. The second is the interaction of the first variable and the government leverage variable. The estimation results are presented in Table VIII. All variables are in first difference form. As before, the results show a significant negative relation between government and corporate debt, though one that is slightly smaller than that found in Columns (4) and (6) of Table II. The interaction term is negative and statistically significant suggesting that foreign ownership increased competition for safe assets consistent with the findings of Bernanke et al. (2011) - and magnified the substitution away from corporates to Treasuries.

Using the coefficient estimates from column (2), we see that the marginal effect of the change in government debt is $(-.034+-0.004 \mathrm{x}$ Foreign Holdings). To gauge the economic magnitude of the interaction, we consider varying the foreign holdings wedge from $1 \%$ - the average value of the foreign holdings wedge before 1970 - to $14 \%$ - the average after 1969 . This 
variation corresponds to an increase in the magnitude of the marginal effect of government debt on corporate debt from -0.038 to -0.09 .

The foreign holdings wedge peaked in 2008 at 30\%, implying a marginal effect of government debt on corporate debt of over -0.15. Foreign ownership of Treasuries in excess of corporate bonds significantly amplifies the magnitude of the relation between government and corporate debt policies. Thus, our findings suggest that growing foreign demand for US treasuries did not relax a binding lending constraint for domestic intermediaries. Rather, our results are consistent with the increased competition view of Bernanke et al. (2011), in which domestic intermediaries fill part of their demand for safe assets with safe corporate debt only when Treasury supply is insufficient.

Additional supporting evidence can be found in time variation in the sensitivity of corporate policies to government debt. As seen earlier in rows (7) and (8) in Panel B of Table II, corporate leverage is three times more sensitive to government leverage in the second half of our sample than in the first. Indeed, the coefficient estimate from the second half of this split-sample regression, -0.099, is quite close in magnitude to the estimated marginal effect from the interaction regression discussed above.

\section{Investment}

Our model of corporate investment follows closely that of Philippon (2009):

$$
\frac{I_{t}^{C}}{A_{t-1}}=\alpha+\beta\left(\frac{Q_{t}^{G}-Q_{t-1}^{G}}{A_{t-1}}\right)+\Gamma X_{t}+\varepsilon_{t}
$$

where $I_{t}^{C}$ is corporate investment, defined as the change in net property, plant, and equipment, and all other variables are as previously defined. The control variables include a proxy for investment opportunities, the market-to-book ratio. We also include the ratio of net income to total assets to capture cash flow effects correlated with financing frictions (Fazarri, Hubbard, and Petersen (1988)), market power (Cooper and Ejarque (2003), or fundamentals (Gomes (2001)). As a robustness test, we include lagged investment as an additional control variable suggested by Eberly, Rebello, and Vincent (2012). We include macroeconomic factors to address concerns about mismeasured investment opportunities and a shifting supply of corporate debt. Specifically, we include the return on three-month Treasury bills, the BAA - ten-year Treasury 
yield spread, inflation, and federal government expenditures. All flow variables are contemporaneous with investment. Stock variables and interest rates are lagged one period. ${ }^{12}$

Panel A of Table IX presents the estimation results for corporate investment - equation (6) above. Columns (1) through (4) show that corporate investment is significantly negatively correlated with the flow of government debt. Moving across the columns, we see a slight increase in the coefficient estimate after adding in macroeconomic controls, though this difference is economically small. Adding in conventional firm characteristics - the market-tobook ratio and net income-to-asset ratio - leads to a noticeable attenuation in the coefficient estimate but still an economically and statistically large relation. The estimate from column (3) implies that a one standard deviation increase in the flow of government debt is associated with a 0.32 standard deviation decrease in corporate investment. Unlike the financial policy variables, this is not the most economically significant marginal effect.

The fourth column incorporates lagged investment (Eberly, Rebello, and Vincent (2012)), which leads to a fairly sharp decline in the magnitude of the government debt coefficient estimate - from -0.094 to -0.048 . However, the estimate is still highly statistically significant and of similar magnitude to that found in the net long-term debt issuance regressions in Table III.

In untabulated results, we estimate the investment specification in column (3) over different subsamples and find that the sensitivity of corporate investment to government borrowing is -0.089 pre-1969, and -0.126 post-1968. The difference is statistically insignificant but mimics the differential sensitivities found for leverage and net debt issuances. Corporate policies, including investment, are more sensitive to government borrowing in the second half of our sample.

Panel B of Table IX presents cross-sectional results similar to those found in Table V. We estimate equation (5) where the dependent variable is net investment divided by total assets. The control variables are those found in column (3) of Panel A. We report only the coefficient on government net debt issuances. The results show that larger firms and firms with a lower probability of default have investment policies that are more sensitive to government borrowing than smaller and riskier firms. The difference in sensitivities across financial constraint strata is economically small. The average difference across the three proxies is 0.027 - a more modest

\footnotetext{
${ }^{12}$ In unreported analysis we also include a linear trend as a control variable. Our results below are qualitatively similar.
} 
estimate than that found in in the aggregate regressions. While still an economically significant result, we recognize that the impact of government borrowing on the cross section of corporate behavior is concentrated more heavily among debt and liquidity policies.

\section{Conclusion}

We show that government debt plays an important role in shaping corporate behavior. Increases in the supply of Treasuries alter relative asset prices such that corporations reduce their debt issuances and investment, and increase their purchases of liquid assets. These relations are concentrated among large, financially healthy firms whose debt is arguably a closer substitute for Treasury securities. Further, these relations are also stronger after 1970, when increasing foreign competition for Treasuries led domestic intermediaries to turn to safe corporate debt to fill part of their demand for safe assets in response to Treasury supply fluctuations. Our results suggest that corporations engage in liquidity provision that alters both the liability and asset structures of their balance sheets in response to the provision of liquidity by the federal government. 


\section{References}

Acharya, Viral, Heitor Almeida and Murillo Campello, 2005, Is cash negative debt? A hedging perspective on corporate financial policies, NBER Working Paper.

Auerbach, Alan and Robert King, 1983, Taxation, portfolio choice, and debt-equity ratios: A general equilibrium model, Quarterly Journal of Economics 98, 587-609.

Baker, Malcolm, 2009, Capital market-driven corporate finance, in Annual Review of Financial Economics, ed. Andrew Lo and Robert Merton.

Baker, Malcolm, Robin Greenwood, and Jeffrey Wurgler, 2003, The maturity of debt issues and predictable variation in bond returns, Journal of Financial Economics 70, 261-291.

Baker, Malcolm, Jeremy Stein, and Jeffrey Wurgler, 2003, When does the market matter? Stock prices and the investment of equity-dependent firms, Quarterly Journal of Economics 118, 9691005.

Barro, Robert, 1974, Are government bonds net wealth? Journal of Political Economy 82, 10951117.

Benninga, Simon and Eli Talmor, 1988, The interaction of corporate and government financing in general equilibrium, Journal of Business 61, 233-258.

Bernanke, Ben, Carol Bertaut, Laurie Pounder DeMarco, and Steven Kamin, 2011, International Capital Flows and the Returns to Safe Assets in the United States, 2003-2007, International Finance Discussion Papers, Board of Governors of the Federal Reserve System.

Blinder, Alan S. and Robert M. Solow, Does fiscal policy matter? Journal of Public Economics 2, 319-337.

Bolton, Patrick and Xavier Freixas, 2000, Equity, Bonds, and Bank Debt: Capital Structure and Financial Market Equilibrium under Asymmetric Information, Journal of Political Economy 108, 324-351.

Cooper, Russell and Joao Ejarque, 2003, Financial frictions and investment: Requiem in Q, Review of Economic Dynamics 6, 710-728.

Eberly, Jan, Sergio Rebello and Nicholas Vincent, 2012, What explains the lagged investment effect? Journal of Monetary Economics 59, 370-380.

Elmendorf, Douglas and N. Gregory Mankiw, 1998, Government debt, NBER Working paper 6470 .

Fama, Eugene and Ken French, 2005, Financing decisions: Who issues stock? Journal of Financial Economics 76, 549-582. 
Faulkender, Michael and Mitchell Petersen, 2005, Does the source of capital affect capital structure? Review of Financial Studies 19, 45-79.

Faulkender, Michael and Rong Wang, 2006, Corporate financial policy and the value of cash, Journal of Finance 61, 1957-1990.

Fazzarri, Steven, R. Glenn Hubbard and Bruce Petersen, 1988, Financing constraints and corporate investment, Brookings Papers on Economic Activity 1, 141-195.

Frank, Murray and Vidhan Goyal, 2008, Trade-off and pecking order theories of capital structure, in Handbook of Corporate Finance: Empirical Corporate Finance, ed. Espen Eckbo, Elsevier.

Frank, Murray and Vidhan Goyal, 2009, Capital structure decisions: Which factors are reliably important? Financial Management 38, 1-37.

Friedman, Benjamin, 1978, Crowding out or crowding in? Economic consequences of financing government deficits. Brookings papers on Economic Activity: 593-641.

Friedman, Milton, 1972, Comments on the critics, Journal of Political Economy 80, 906-950.

Gomes, Joao, 2001, Financing investment, American Economic Review 91, 1263-1285.

Gorton, Gary, Stefan Lewellen and Andrew Metrick, 2013, The safe asset share, American Economic Review 102, 101-106.

Gorton, Gary and Andrew Winton, 2003, Financial intermediation, in the Handbook of the Economics of Finance, eds. George Constantinides, Milton Harris, and Rene Stulz, Elsevier.

Graham, John R. and Mark T. Leary, 2011, A review of empirical capital structure research and directions for the future, in Annual Review of Financial Economics, ed. Andrew Lo and Robert Merton.

Graham, John R., Mark T. Leary, and Michael R. Roberts, 2013, A century of capital structure: The leveraging of corporate America, forthcoming Journal of Financial Economics.

Granger, Clive and Paul Newbold, 1974, Spurious regression, Journal of Econometrics 2, 111120.

Greenwood, Robin, Samuel Hanson and Jeremy Stein, 2010, A gap-filling theory of corporate debt maturity choice, Journal of Finance 65, 993-1028.

Greenwood, Robin and Dimitry Vayanos, 2013, Bond supply and excess bond returns, Review of Financial Studies 27, 663-713. 
Hadlock, Charles and Joshua Pierce, 2010, New Evidence on Measuring Financial Constraints: Moving Beyond the KZ Index, Review of Financial Studies 23, 1909 - 1940.

Hubbard, Glenn, 2011, Consequences of government deficits and debt, Working Paper.

James, Christopher and Dominique Badoer, 2013, The determinants of long-term corporate debt issuances, Working Paper.

Jensen, Michael and William Meckling, 1976, A theory of the firm: Managerial behavior, agency costs, and ownership structure, Journal of Financial Economics 3, 305-360.

Kaplan, Steven and Per Stromberg, 2009, Leveraged buyouts and private equity, Journal of Economic Perspectives 2009, 1-27.

Kashyap, Anil, Owen Lamont and Jeremy Stein, 1994, Credit conditions and the cyclical behavior of inventories, Quarterly Journal of Economics, 109, 565 - 592.

Korajczyk, Robert and Amnon Levy, 2003, Capital structure choice: macroeconomic conditions and financial constraints, Journal of Financial Economics 68, 75 - 109.

Krishnamurthy, Arvind and Annette Vissing-Jorgensen, 2012, The aggregate demand for Treasury debt, Journal of Political Economy 120, 233-267.

Krishnamurthy, Arvind and Annette Vissing-Jorgensen, 2013, Short-term debt and the financial crisis: What we can learn from US Treasury supply, Working Paper.

Leary, Mark, 2009, Bank Loan Supply, Lender Choice, and Corporate Capital Structure. Journal of Finance, 64, 1143-1185.

Lemmon, Michael and Michael R. Roberts, 2010, The response of corporate financing and investment to changes in the supply of credit, Journal of Financial and Quantitative Analysis 45, 555-587.

Lemmon, Michael, Michael R. Roberts and Jaime Zender, 2008, Back to the beginning: Persistence and the cross-section of corporate capital structures, Journal of Finance 63, 15751608.

McDonald, Robert, 1983, Government debt and private leverage: An extension of the Miller theorem, Journal of Public Economics 22, 303-325.

Merton, Robert, 1974, On the pricing of corporate debt: The risk structure of interest rates, Journal of Finance 29, 449-470.

Miller, Merton, 1977, Debt and Taxes, Journal of Finance 32, 261-275. 
Modigliani, Franco and Merton Miller, 1958, The cost of capital, corporation finance and the theory of investment, American Economic Review 48, 261-297.

Newey, Whitney and Ken West, 1987, A simple, positive-definite, heteroskedasticity and autocorrelation consistent covariance matrix, Econometrica 55, 703-708.

Philippon, Thomas, 2009, The bond market's q, Quarterly Journal of Economics 129, 10111056.

Rajan, Raghuram and Luigi Zingales, 1995, What do we know about capital structure: Some evidence from international data. Journal of Finance 50, 1421-1460.

Robichek, Alexander and Stewart Myers, 1966, Problems in the theory of optimal capital structure, Journal of Financial and Quantitative Analysis 1, 1-35.

Rubinstein, Mark, 1973, Corporate financial policy in segmented securities markets, Journal of Financial and Quantitative Analysis 8, 749-761.

Shivdasani, Anil and Marc Zenner, 2005, How to choose a capital structure: Navigating the debtequity decision, Journal of Applied Corporate Finance 17, 26 - 35.

Taggart, Robert A., 1985, Secular patterns in corporate finance, in Corporate Capital Structures in the United States, ed. Benjamin Friedman, University of Chicago Press.

Tobin, James and William Buiter, 1976, Long-run effects of fiscal and monetary policy on aggregate demand, in Monetarism, ed. Jerome L. Stein, American Elsevier. 


\section{Appendix A: Variable Definitions, Construction, and Sources}

The tables of this appendix provide details on the definitions and construction of variables used in the study. Data sources are also provided. 

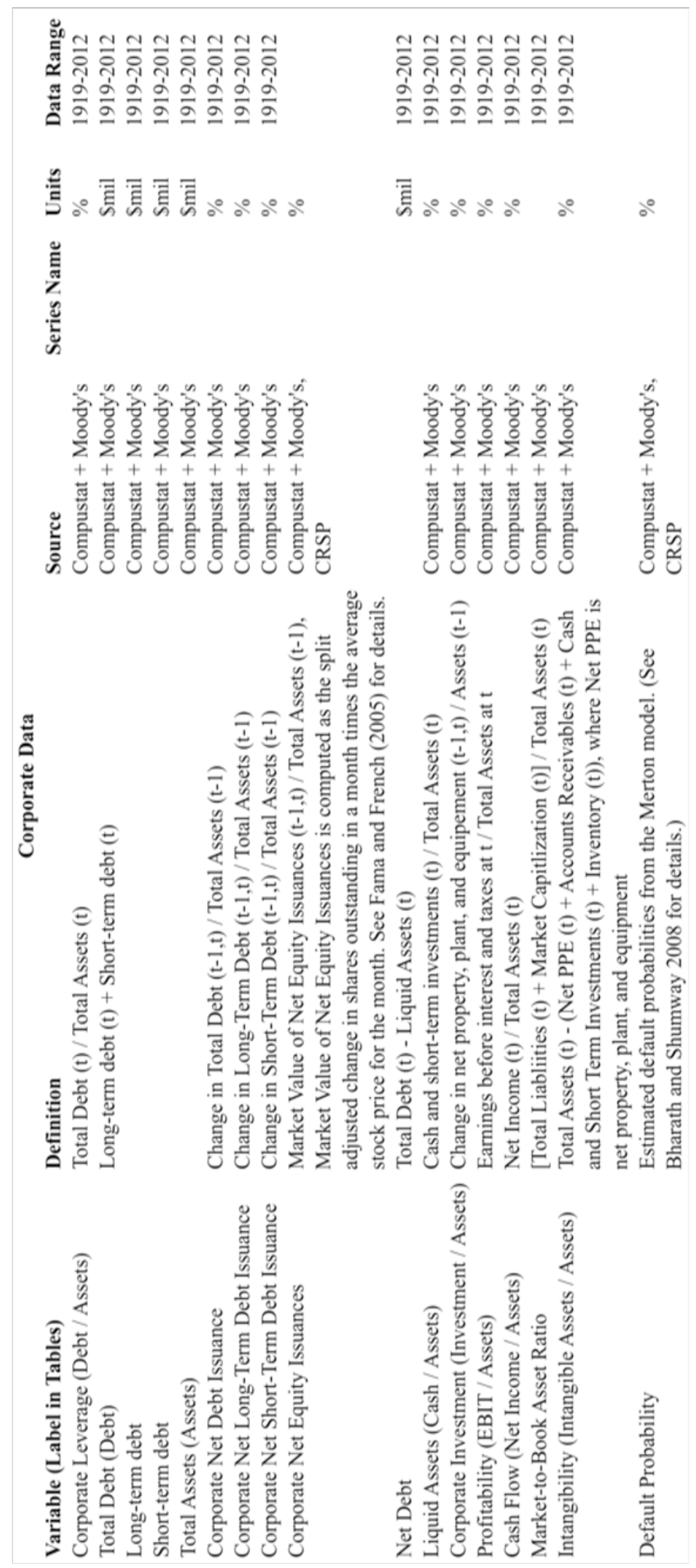

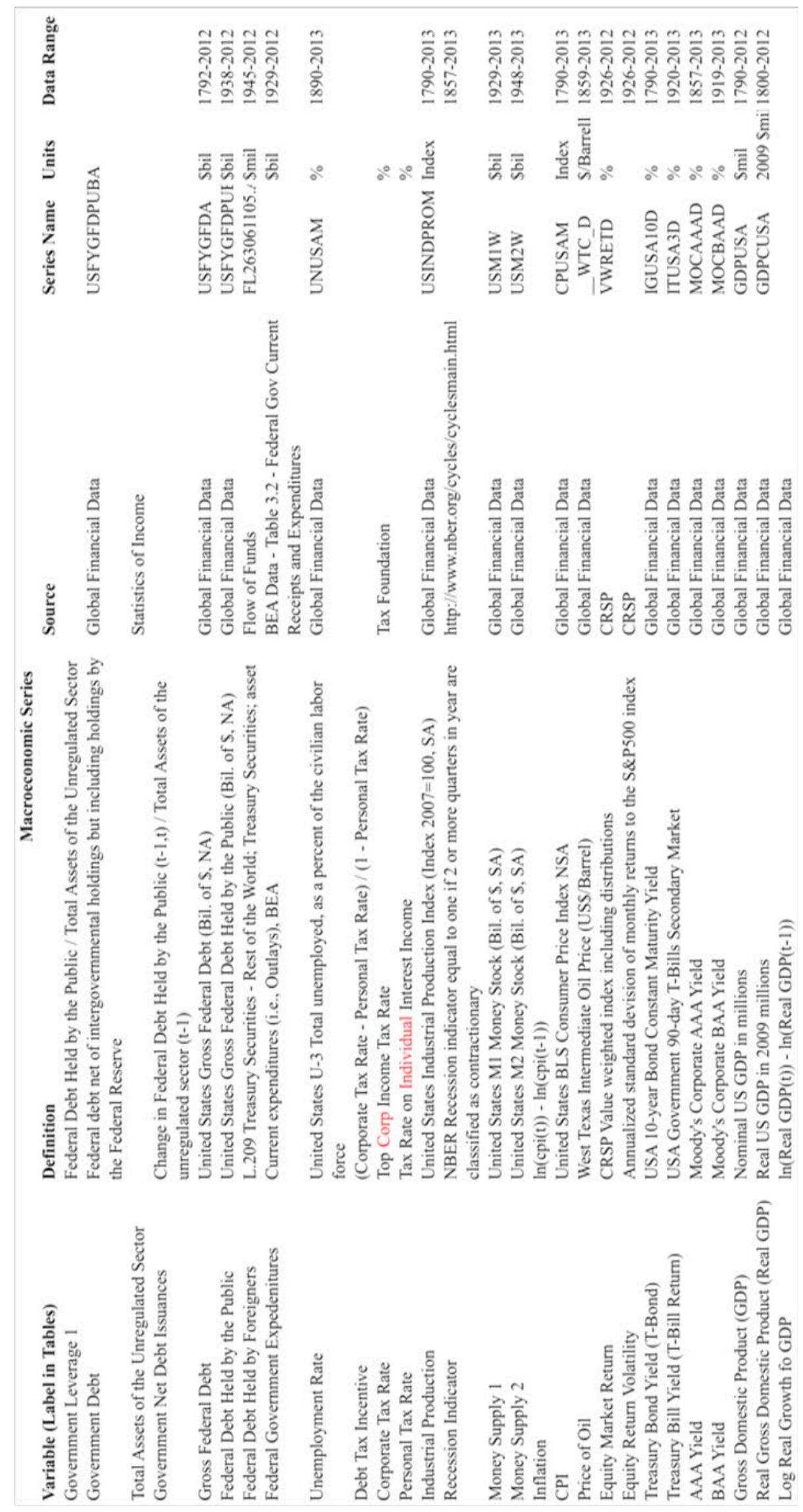
Figure 1

\section{Regulated vs. Unregulated Assets}

The figure presents the annual time series of the fraction of total assets owned by unregulated firms defined as those firms not in the utility, railroad, or transportation industries.

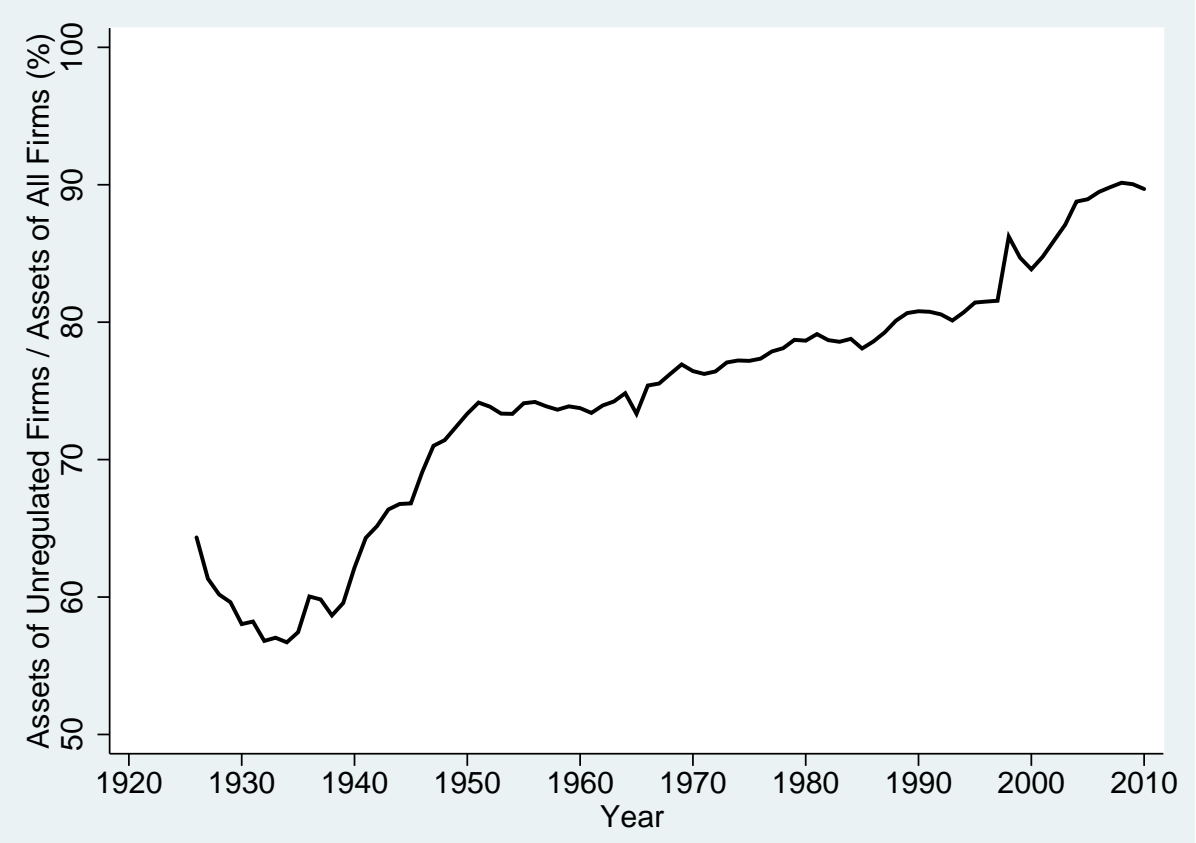




\section{Figure 2}

\section{Government Debt and Corporate Policies}

The figure presents annual time series of government leverage and corporate leverage (Panel A) and corporate liquidity (Panel B). Corporate leverage is the ratio of all interest bearing debt to total assets. Corporate liquidity is the ratio of cash and short-term investments to total assets. Government leverage is the ratio of federal debt held by the public to GDP.

\section{Panel A: Corporate Leverage}

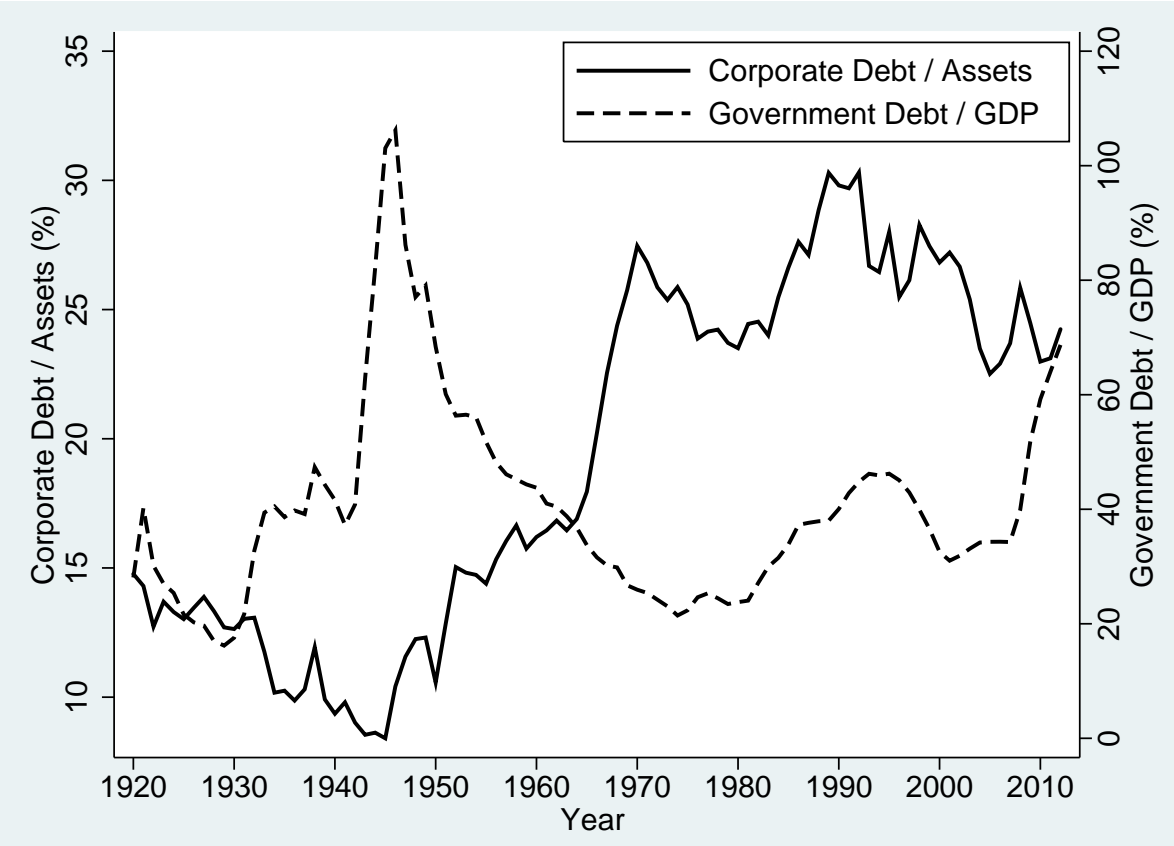

Panel B: Corporate Liquidity

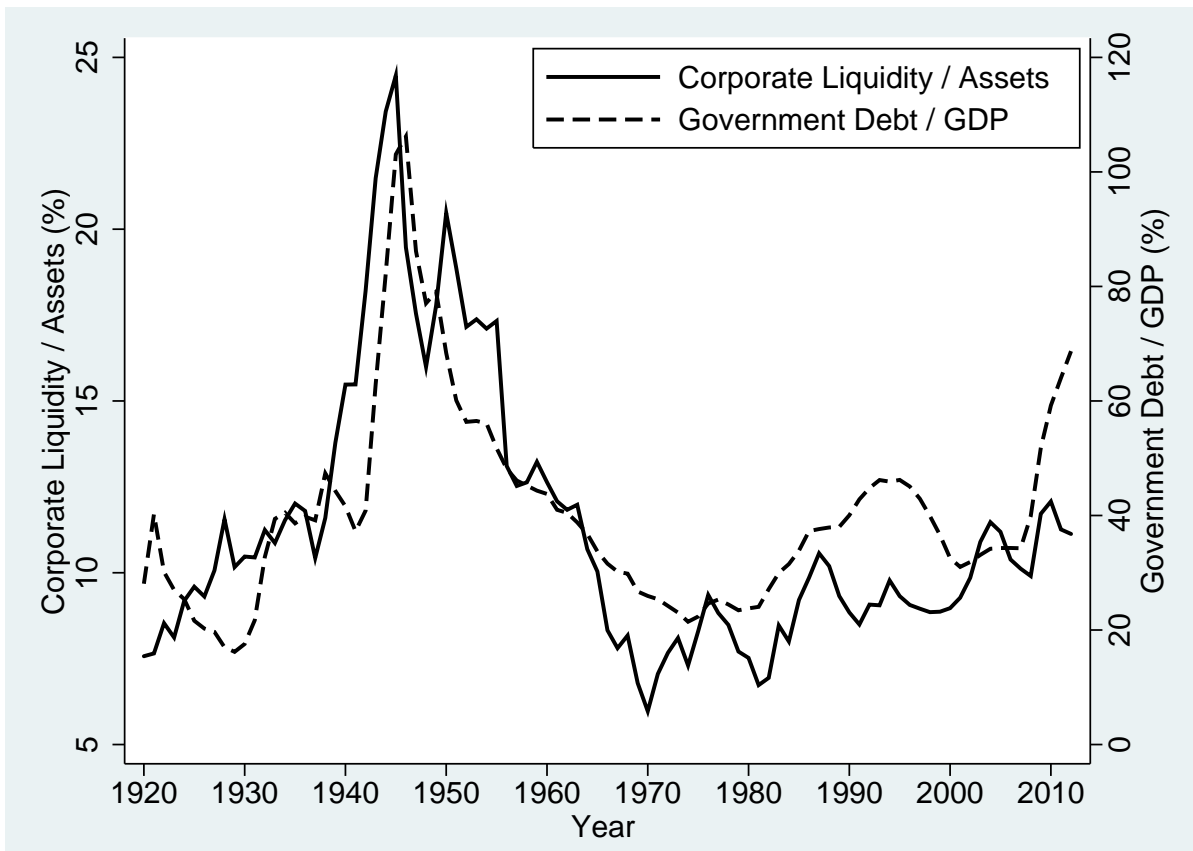




\section{Figure 3}

\section{Distribution of Corporate Bond Holdings}

The figure presents the distribution of corporate and foreign bond holdings from the Flow of Funds. The categories are defined as follows. 1) Households: Households and nonprofit organizations; 2) Government: State and local governments, excluding employee retirement funds plus Federal government; 3) Foreigners: Rest of the world. 4) Banks: U.S.-chartered depository institutions plus Foreign banking offices in the U.S. plus Banks in U.S.-affiliated areas plus Credit unions 5) Insurance: Property-casualty insurance companies plus life insurance companies 6) Pension: Private pension funds plus state and local government employee retirement funds plus federal government retirement funds 7) Funds: Money market mutual funds plus mutual funds plus closed-end funds plus exchange-traded funds 8) Other: Government-sponsored enterprises plus finance companies plus real estate investment trusts plus security brokers and dealers plus holding companies plus funding corporations.

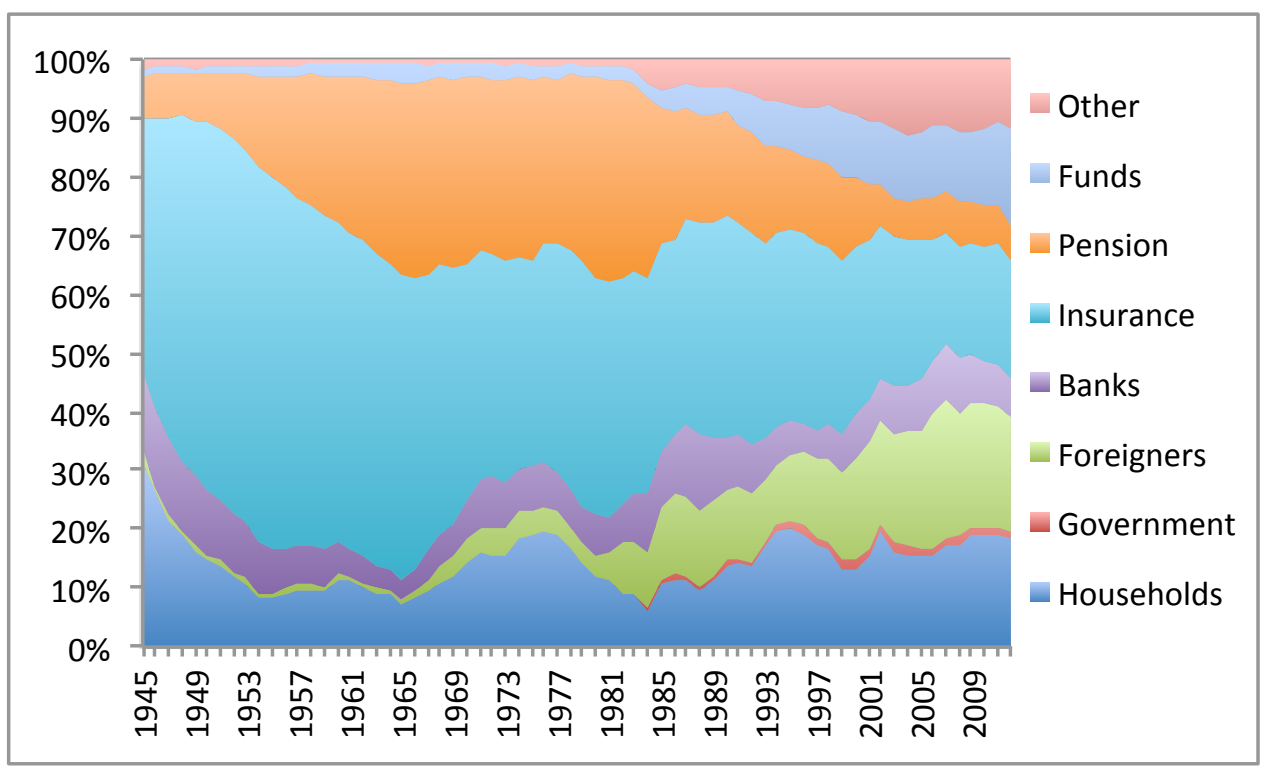




\section{Figure 4}

\section{Financial Intermediary Asset Allocation Among Credit Market Instruments}

The figure presents the annual portfolio allocations across credit instruments for US Commercial Banks (Panel A), Life and Property \& Casualty Insurance Companies (Panel B), and State and Local Pension Funds (Panel C).

Panel A: Commercial Banks

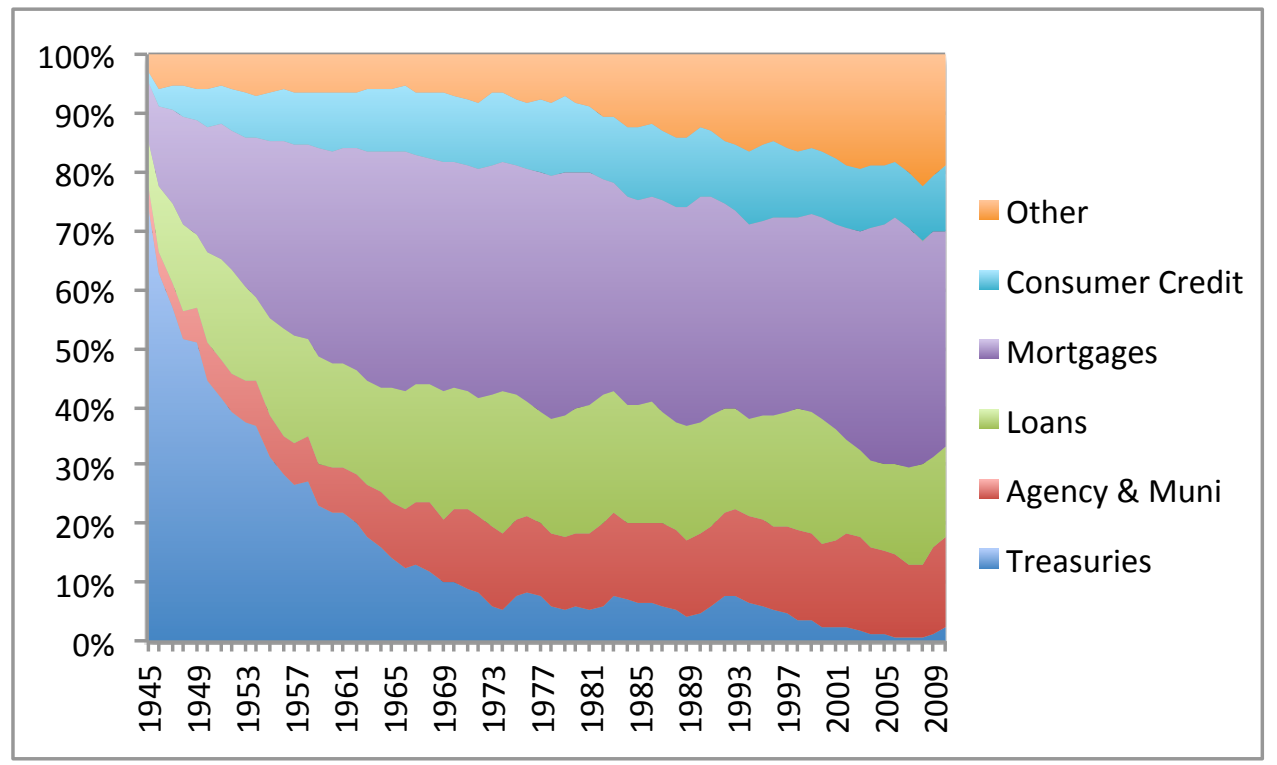

Panel B: Life and Property \& Casualty Insurance Companies

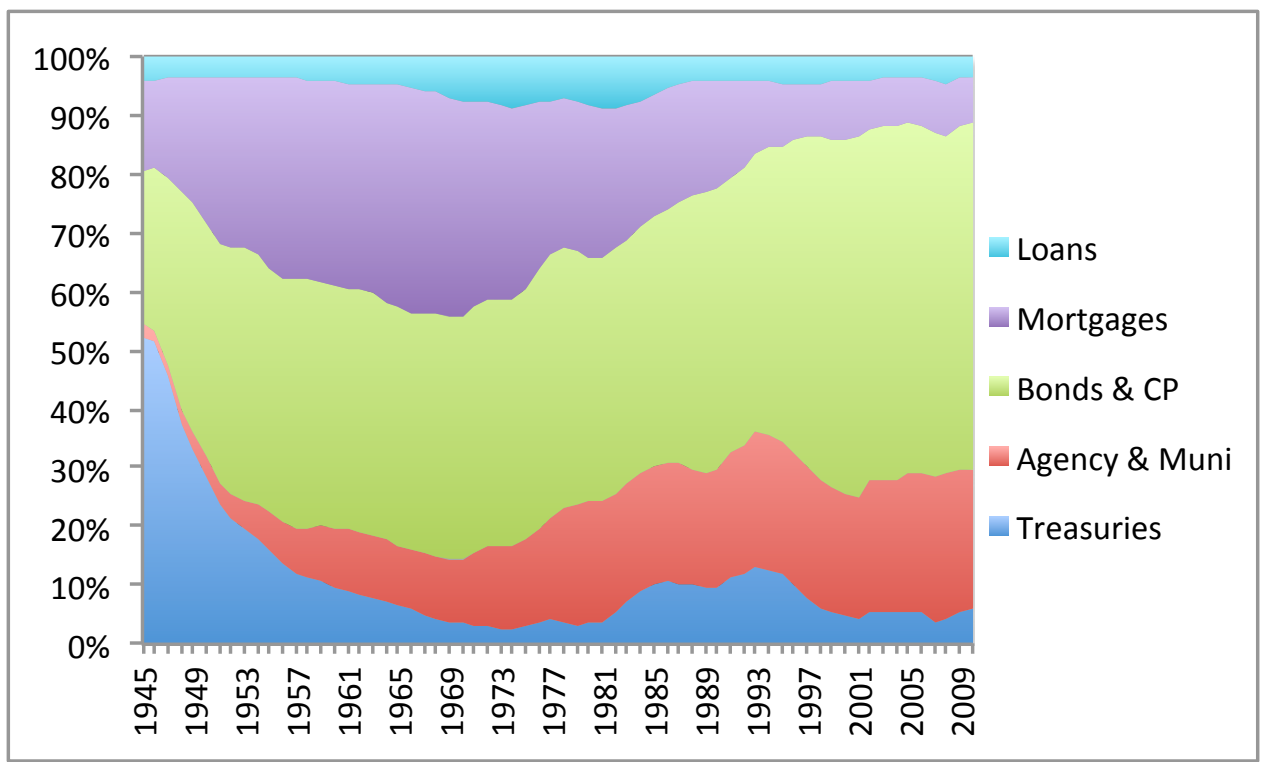


Panel C: State and Local Pension Funds

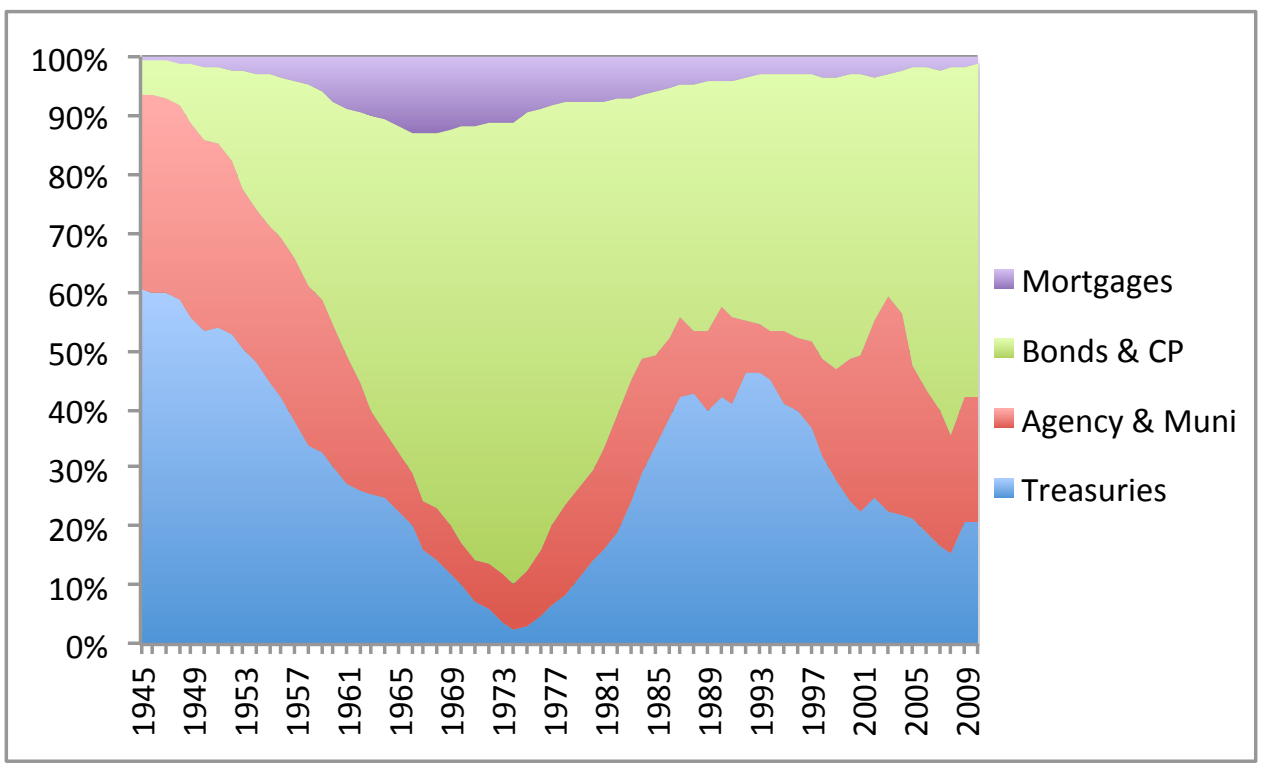




\section{Figure 5}

\section{Foreign Holdings of US Government and Corporate Debt}

The figure presents the distribution of foreign and domestic holdings of US Treasury debt and US corporate bonds. The solid line presents the percentage of US Treasury debt held by foreigners as a fraction of total outstanding Treasury debt. The dashed line presents the percentage of US corporate bonds held by foreigners as a fraction of total outstanding US corporate bonds.

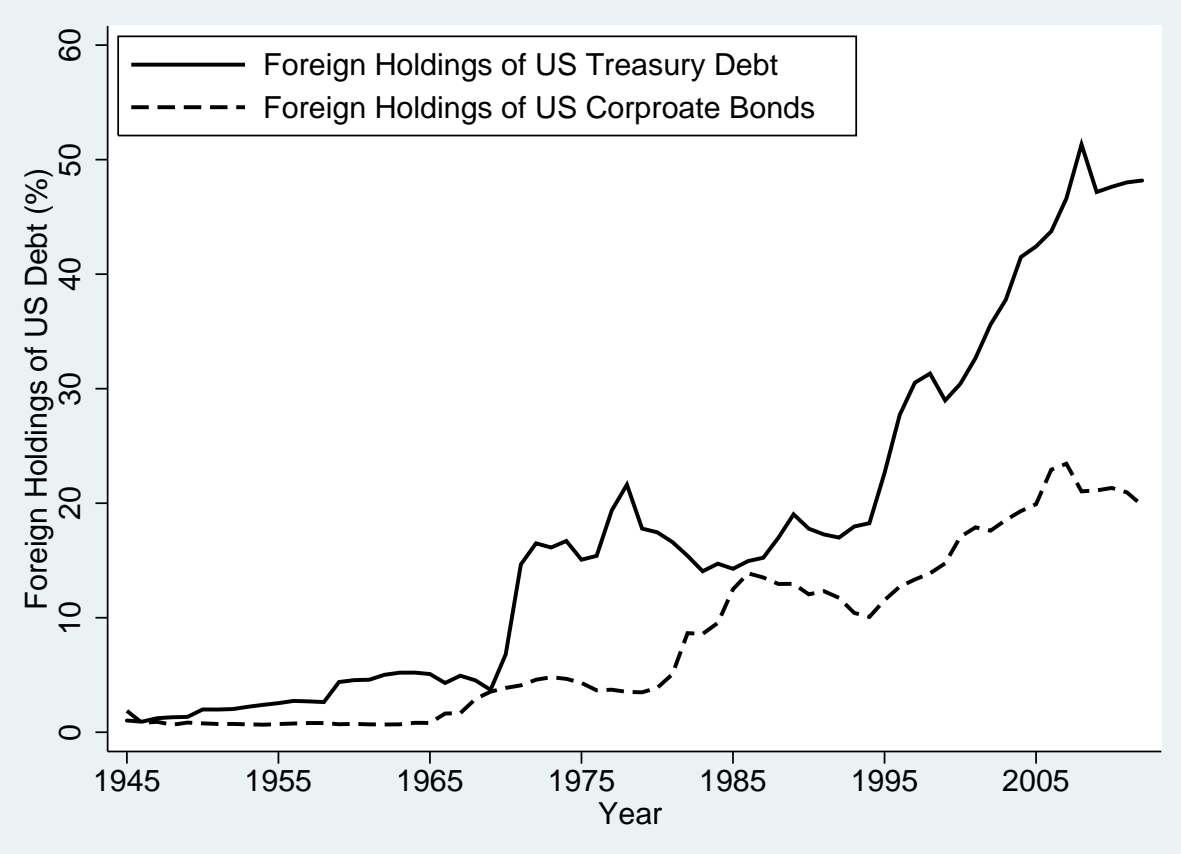




\section{Table I}

\section{Summary Statistics}

Panel A presents summary statistics for the aggregate time series. Panel B presents summary statistics for the firm-level panel data. All variables are presented as percentages, except the market-to-book asset ratio. $\mathrm{AR}(1)$ is the ordinary least squares estimate of the slope parameter from a first order autoregression. All ratios in the firm-level panel are Winsorized at the upper and lower 1\%. All variables are formally defined in Appendix A.

Panel A: Aggregate Time Series

\begin{tabular}{lcccccc} 
& Obs & Mean & SD & Min & Max & AR(1) \\
\hline Corporate Financial \& Investment Policy & & & & & & \\
Debt / Assets & 93 & 19.36 & 6.82 & 8.41 & 30.31 & 0.99 \\
(Debt - Cash) / Assets & 93 & 8.08 & 9.80 & -16.06 & 21.47 & 0.98 \\
Corp Net Debt Issuances / Assets(t-1) & 93 & 1.76 & 1.69 & -1.61 & 5.60 & 0.60 \\
Corp Net Equity Issuances / Assets(t-1) & 87 & 1.43 & 1.69 & -0.93 & 8.94 & 0.66 \\
Investment / Assets & 93 & 2.91 & 2.27 & -3.48 & 6.97 & 0.70 \\
Firm Characteristics & & & & & & \\
EBIT / Assets & 93 & 10.14 & 3.05 & 1.86 & 18.34 & 0.81 \\
Net Income / Assets & 93 & 5.76 & 2.04 & 0.00 & 10.87 & 0.76 \\
Market-to-Book Asset Ratio & 88 & 1.27 & 0.25 & 0.57 & 1.90 & 0.79 \\
Cash / Assets & 93 & 11.28 & 3.87 & 5.97 & 24.47 & 0.94 \\
Intangible Assets / Assets & 93 & 16.11 & 9.85 & 5.99 & 36.53 & 1.02 \\
Macroeconomic Variables & & & & & & \\
T-Bill Return & 93 & 3.61 & 2.96 & 0.02 & 14.30 & 0.90 \\
BAA - T-Bond Spread & 93 & 2.13 & 1.04 & 0.39 & 6.16 & 0.68 \\
Inflation & 92 & 2.69 & 4.22 & -11.46 & 16.66 & 0.59 \\
Equity Market Return & 87 & 11.58 & 20.31 & -44.36 & 57.50 & 0.01 \\
Log Real Growth of GDP & 92 & 3.31 & 5.16 & -13.93 & 16.99 & 0.37 \\
Government Variables & & & & & & \\
Gov Debt / Assets & 85 & 45.63 & 34.51 & 13.38 & 184.80 & 0.96 \\
Gov Net Debt Issuances / Assets(t-1) & 85 & 3.42 & 8.57 & -12.34 & 50.45 & 0.76 \\
Gov Exp / Assets & 83 & 20.71 & 10.40 & 2.61 & 56.39 & 0.92 \\
\hline
\end{tabular}


Panel B: Panel Data

\begin{tabular}{lccccc} 
& Obs & Mean & SD & Min & Max \\
\hline Corporate Financial É Investment Policy & & & & & \\
Corp Total Debt / Assets & 222,940 & 21.73 & 20.09 & 0.00 & 88.35 \\
(Debt - Liquid Assets) / Assets & 222,779 & 5.40 & 33.00 & -86.09 & 81.93 \\
Corp Net Debt Issuances / Assets(t-1) & 200,667 & 3.57 & 15.81 & -31.42 & 89.20 \\
Corp Net Equity Issuances / Assets(t-1) & 194,044 & 9.95 & 35.46 & -16.59 & 252.49 \\
Investment / Assets & 199,991 & 1.11 & 60.53 & -291.90 & 339.36 \\
Firm Characteristics & & & & & \\
EBIT / Assets & 220,042 & 3.14 & 21.85 & -112.62 & 36.68 \\
Net Income / Assets & 222,476 & -1.87 & 23.04 & -133.21 & 25.02 \\
Market-to-Book Asset Ratio & 213,323 & 1.76 & 1.61 & 0.36 & 10.74 \\
Liquid Assets / Assets & 222,791 & 16.37 & 19.39 & 0.04 & 88.28 \\
Intangible Assets / Assets & 218,850 & -196.05 & 588.67 & $-3,858.87$ & 93.18 \\
\hline
\end{tabular}




\section{Table II \\ Corporate Leverage}

Panel A presents OLS estimates and t-statistics in parentheses from time series regressions of aggregate corporate leverage on macroeconomic factors and firm characteristics. Columns (1) through (3) present results using the level of all variables, columns (4) through (6) using first differences. Panel B presents the coefficient estimate on the government leverage variable from a series of different OLS estimations. Each specification includes as controls, all of the macroeconomic variables and firm characteristics presented in columns (3) and (6) of Panel A. Rows (1) through (3) change the definition of the dependent variable. Row (4) adds a debt tax incentive variable to the controls; Row (5) adds the following control variables: debt tax incentive, real price of oil, unemployment rate, growth rate of M1, growth rate of real assets, one period lag and future real GDP growth, an indicator identifying NBER recessions, and the T-Bond - T-Bill spread. Rows (6) through (9) exclude different periods from the estimation sample. Rows (10) through (11) use different samples of firms. All control variables are contemporaneous with the dependent variable and formally defined in Appendix A. Newey-West standard errors assuming two non-zero lags are used to compute all t-statistics (in parentheses). Statistical significance at the 10\%, $5 \%$ and $1 \%$ levels are indicated by “*”, “**”, and “***”, respectively.

Panel A: Dependent Variable $=$ Corporate Debt / Assets

\begin{tabular}{|c|c|c|c|c|c|c|}
\hline & \multicolumn{3}{|c|}{ Levels } & \multicolumn{3}{|c|}{ First Differences } \\
\hline & (1) & $(2)$ & (3) & $(4)$ & $(5)$ & (6) \\
\hline \multirow[t]{2}{*}{ Gov Debt / Assets } & $-0.046^{* * *}$ & $-0.082^{* * *}$ & $-0.053^{*}$ & $-0.025^{* *}$ & $-0.036^{* *}$ & $-0.039 * *$ \\
\hline & $(-5.900)$ & $(-3.147)$ & $(-1.902)$ & $(-2.389)$ & $(-2.375)$ & $(-2.179)$ \\
\hline \multicolumn{7}{|l|}{ Macroeconomic Variables } \\
\hline \multirow[t]{2}{*}{ T-Bill Return } & & 0.358 & 0.260 & & -0.031 & -0.010 \\
\hline & & $(1.423)$ & $(1.071)$ & & $(-0.380)$ & $(-0.108)$ \\
\hline \multirow[t]{2}{*}{ BAA - T-Bond Spread } & & -0.117 & -0.274 & & $0.286^{* *}$ & $0.303^{*}$ \\
\hline & & $(-0.247)$ & $(-0.518)$ & & $(1.978)$ & $(1.841)$ \\
\hline \multirow[t]{2}{*}{ Inflation } & & -0.032 & 0.055 & & -0.016 & 0.020 \\
\hline & & $(-0.424)$ & $(0.725)$ & & $(-0.580)$ & $(0.578)$ \\
\hline \multirow[t]{2}{*}{ Equity Market Return } & & -0.003 & -0.017 & & 0.004 & -0.001 \\
\hline & & $(-0.280)$ & $(-1.392)$ & & $(0.999)$ & $(-0.138)$ \\
\hline \multirow[t]{2}{*}{ Log Real Growth of GDP } & & $-0.206^{* * *}$ & -0.112 & & $-0.087^{* * *}$ & $-0.061^{* *}$ \\
\hline & & $(-3.252)$ & $(-1.541)$ & & $(-3.150)$ & $(-2.241)$ \\
\hline \multirow[t]{2}{*}{ Gov Exp / Assets } & & $0.184^{* *}$ & 0.086 & & 0.003 & 0.004 \\
\hline & & $(2.190)$ & $(0.976)$ & & $(0.100)$ & $(0.113)$ \\
\hline \multicolumn{7}{|l|}{ Firm Characteristics } \\
\hline \multirow[t]{2}{*}{ EBIT / Assets } & & & $-0.539^{* *}$ & & & $-0.195^{* *}$ \\
\hline & & & $(-2.500)$ & & & $(-1.996)$ \\
\hline \multirow[t]{2}{*}{ Intangible Assets / Assets } & & & -0.235 & & & -0.071 \\
\hline & & & $(-1.631)$ & & & $(-0.416)$ \\
\hline \multirow[t]{2}{*}{ Market-to-Book Asset Ratio } & & & 0.260 & & & 0.676 \\
\hline & & & $(0.145)$ & & & $(0.701)$ \\
\hline Trend & Yes & Yes & Yes & No & No & No \\
\hline Adjusted $R^{2}$ & 0.802 & 0.884 & 0.898 & 0.035 & 0.214 & 0.226 \\
\hline Observations & 85 & 82 & 82 & 84 & 81 & 81 \\
\hline
\end{tabular}


Panel B: Robustness Tests (Estimates of Government Leverage Coefficient)

(1)

\begin{tabular}{cc}
\hline Alternative Measures of Corporate Leverage & \\
(1) (Debt - Cash) / Assets & $-0.082^{* * *}$ \\
& $(-3.064)$ \\
(2) Corp LT Debt / Assets & $-0.024^{*}$ \\
& $(-1.870)$ \\
(3) Corp ST Debt / Assets & $-0.020^{* * *}$ \\
& $(-3.163)$ \\
Changes to the X-Variables & \\
(4) Additional Control Variables & $-0.057^{* * *}$ \\
& $(-3.473)$ \\
Scale and by GDP & $-0.030^{* *}$ \\
(5) Corp Total Debt / GDP & $(-2.565)$ \\
& \\
Subperiods & $-0.089^{* * *}$ \\
(6) Excluding Years 1942-1955 & $(-3.087)$ \\
(7) Pre-1969 & $-0.031^{*}$ \\
(8) Post-1968 & $(-1.804)$ \\
(9) No Recession Years & $-0.099^{* * *}$ \\
Alternative Samples & $(-2.827)$ \\
(10) 500 Largest Firms & $-0.046^{* *}$ \\
(11) NYSE Firms & $(-2.080)$ \\
\hline
\end{tabular}




\section{Table III}

\section{Corporate Financing Flows}

The table presents OLS coefficient estimates and t-statistics in parentheses. The dependent variable in each regression is the net financing flow scaled by the start of period total assets and is indicated at the top of each column. For example, the dependent variable in the first column is net debt issuances during period $t$ scaled by start of period total assets. All flow and first difference control variables are contemporaneous with the dependent variable; stock variables and interest rates are lagged one period. All variables are formally defined in Appendix A. Newey-West standard errors assuming two non-zero lags are used to compute all t-statistics (in parentheses). Statistical significance at the $10 \%, 5 \%$ and $1 \%$ levels are indicated by “*”, “**”, and “***”, respectively.

\begin{tabular}{|c|c|c|c|c|}
\hline & \multicolumn{4}{|c|}{ Financing Flow Scaled by Start of Period Total Assets } \\
\hline & \multirow{2}{*}{$\begin{array}{l}\text { Total } \\
\text { Debt }\end{array}$} & \multirow{2}{*}{$\begin{array}{c}\text { Long-Term } \\
\text { Debt }\end{array}$} & \multicolumn{2}{|l|}{ Short-Term } \\
\hline & & & Debt & Equity \\
\hline & $(1)$ & $(2)$ & $(3)$ & $(4)$ \\
\hline Gov Net Debt Issuances / Assets(t-1) & -0.042 & $-0.047^{* *}$ & 0.009 & 0.044 \\
\hline & $(-1.492)$ & $(-2.001)$ & $(0.996)$ & $(0.876)$ \\
\hline \multicolumn{5}{|l|}{ Macroeconomic Variables } \\
\hline \multirow[t]{2}{*}{ T-Bill Return } & $0.209^{* * *}$ & $0.119^{* * *}$ & $0.082^{* * *}$ & 0.060 \\
\hline & $(3.763)$ & $(3.376)$ & $(3.510)$ & $(0.953)$ \\
\hline \multirow[t]{2}{*}{ BAA - T-Bond Spread } & -0.279 & 0.046 & $-0.279^{* *}$ & 0.255 \\
\hline & $(-1.101)$ & $(0.263)$ & $(-2.520)$ & $(1.370)$ \\
\hline \multirow[t]{2}{*}{ Inflation } & $0.074^{* *}$ & 0.041 & $0.032^{* *}$ & 0.011 \\
\hline & ( 2.397) & $(1.626)$ & $(2.036)$ & $(0.311)$ \\
\hline \multirow[t]{2}{*}{ Equity Market Return } & -0.001 & 0.008 & $-0.009^{* * *}$ & $0.017^{* * *}$ \\
\hline & $(-0.223)$ & $(1.458)$ & $(-2.683)$ & $(3.139)$ \\
\hline \multirow[t]{2}{*}{ Log Real Growth of GDP } & -0.015 & $-0.045^{*}$ & 0.020 & -0.028 \\
\hline & $(-0.531)$ & $(-1.848)$ & $(1.521)$ & $(-0.796)$ \\
\hline \multirow[t]{2}{*}{ Gov Exp / Assets } & 0.022 & 0.037 & $-0.019^{*}$ & -0.067 \\
\hline & $(0.675)$ & $(1.310)$ & $(-1.645)$ & $(-1.028)$ \\
\hline \multicolumn{5}{|l|}{ Firm Characteristics } \\
\hline \multirow[t]{2}{*}{ EBIT / Assets } & 0.023 & 0.039 & 0.007 & -0.008 \\
\hline & $(0.296)$ & $(0.625)$ & $(0.230)$ & $(-0.072)$ \\
\hline \multirow[t]{2}{*}{ Intangible Assets / Assets } & 0.026 & 0.018 & 0.004 & $-0.072^{*}$ \\
\hline & $(0.929)$ & $(0.847)$ & $(0.395)$ & $(-1.784)$ \\
\hline \multirow[t]{2}{*}{ Market-to-Book Asset Ratio } & 1.060 & 1.464 & -0.208 & $5.371^{* * *}$ \\
\hline & $(0.857)$ & $(1.619)$ & $(-0.519)$ & $(3.663)$ \\
\hline Adjusted $\mathrm{R}^{2}$ & 0.465 & 0.456 & 0.412 & 0.323 \\
\hline Obs & 83 & 83 & 83 & 83 \\
\hline
\end{tabular}




\section{Table IV}

\section{Corporate Liquid Assets and Government Leverage}

The table presents OLS coefficient estimates and t-statistics in parentheses for regressions of corporate cash and short term investments scaled by assets on macroeconomic factors and firm characteristics. Columns (1) through (3) present results using the level of all variables, columns (4) through (6) using first differences. Newey-West standard errors assuming two non-zero lags are used to compute all tstatistics (in parentheses). Statistical significance at the 10\%, 5\% and 1\% levels are indicated by "**, "**", and "****, respectively.

\begin{tabular}{|c|c|c|c|c|c|c|}
\hline & \multicolumn{3}{|c|}{ Levels } & \multicolumn{3}{|c|}{ First Differences } \\
\hline & $(1)$ & $(2)$ & $(3)$ & $(4)$ & $(5)$ & $(6)$ \\
\hline Gov Debt / Assets & $\begin{array}{c}0.088^{* * *} \\
(9.128)\end{array}$ & $\begin{array}{c}0.103^{* * *} \\
(5.471)\end{array}$ & $\begin{array}{l}0.056^{* *} \\
(2.426)\end{array}$ & $\begin{array}{c}0.064^{* * *} \\
(6.001)\end{array}$ & $\begin{array}{c}0.039^{* * *} \\
(3.437)\end{array}$ & $\begin{array}{c}0.045^{* * *} \\
(3.565)\end{array}$ \\
\hline \multicolumn{7}{|l|}{ Macroeconomic Variables } \\
\hline T-Bill Return & & $\begin{array}{l}-0.302^{* *} \\
(-2.325)\end{array}$ & $\begin{array}{c}-0.256^{* *} \\
(-2.042)\end{array}$ & & $\begin{array}{c}-0.060 \\
(-1.019)\end{array}$ & $\begin{array}{c}-0.066 \\
(-1.066)\end{array}$ \\
\hline BAA - T-Bond Spread & & $\begin{array}{c}0.447 \\
(1.645)\end{array}$ & $\begin{array}{c}-0.127 \\
(-0.540)\end{array}$ & & $\begin{array}{l}-0.192^{* *} \\
(-1.995)\end{array}$ & $\begin{array}{c}-0.262^{* * *} \\
(-2.675)\end{array}$ \\
\hline Inflation & & $\begin{array}{c}-0.066 \\
(-1.101)\end{array}$ & $\begin{array}{c}-0.146^{* *} \\
(-2.374)\end{array}$ & & $\begin{array}{c}-0.044 \\
(-1.184)\end{array}$ & $\begin{array}{c}-0.073^{*} \\
(-1.678)\end{array}$ \\
\hline Equity Market Return & & $\begin{array}{c}0.005 \\
(0.723)\end{array}$ & $\begin{array}{c}0.015^{*} \\
(1.720)\end{array}$ & & $\begin{array}{c}0.003 \\
(0.987)\end{array}$ & $\begin{array}{c}0.009^{*} \\
(1.774)\end{array}$ \\
\hline Log Real Growth of GDP & & $\begin{array}{c}0.198^{* * *} \\
(3.386)\end{array}$ & $\begin{array}{c}0.090 \\
(1.458)\end{array}$ & & $\begin{array}{l}0.069 * * \\
(2.133)\end{array}$ & $\begin{array}{l}0.066^{* *} \\
(2.570)\end{array}$ \\
\hline Gov Exp / Assets & & $\begin{array}{c}-0.043 \\
(-0.720)\end{array}$ & $\begin{array}{c}0.107^{*} \\
(1.828)\end{array}$ & & $\begin{array}{c}0.119^{* * *} \\
(3.962)\end{array}$ & $\begin{array}{c}0.114^{* * *} \\
(3.827)\end{array}$ \\
\hline \multicolumn{7}{|l|}{ Firm Characteristics } \\
\hline EBIT / Assets & & & $\begin{array}{c}0.517^{* * *} \\
(4.900)\end{array}$ & & & $\begin{array}{c}0.159 \\
(1.638)\end{array}$ \\
\hline Intangible Assets / Assets & & & $\begin{array}{c}0.242^{* * *} \\
(3.902)\end{array}$ & & & $\begin{array}{c}0.105 \\
(0.954)\end{array}$ \\
\hline Market-to-Book Asset Ratio & & & $\begin{array}{c}-2.242^{*} \\
(-1.958)\end{array}$ & & & $\begin{array}{c}-1.256 \\
(-1.485)\end{array}$ \\
\hline Earnings Volatility & & & $\begin{array}{c}0.265 \\
(1.037) \\
\end{array}$ & & & $\begin{array}{c}-0.284 \\
(-0.581)\end{array}$ \\
\hline Trend & Yes & Yes & Yes & No & No & No \\
\hline Obs & 85 & 82 & 82 & 84 & 81 & 81 \\
\hline
\end{tabular}




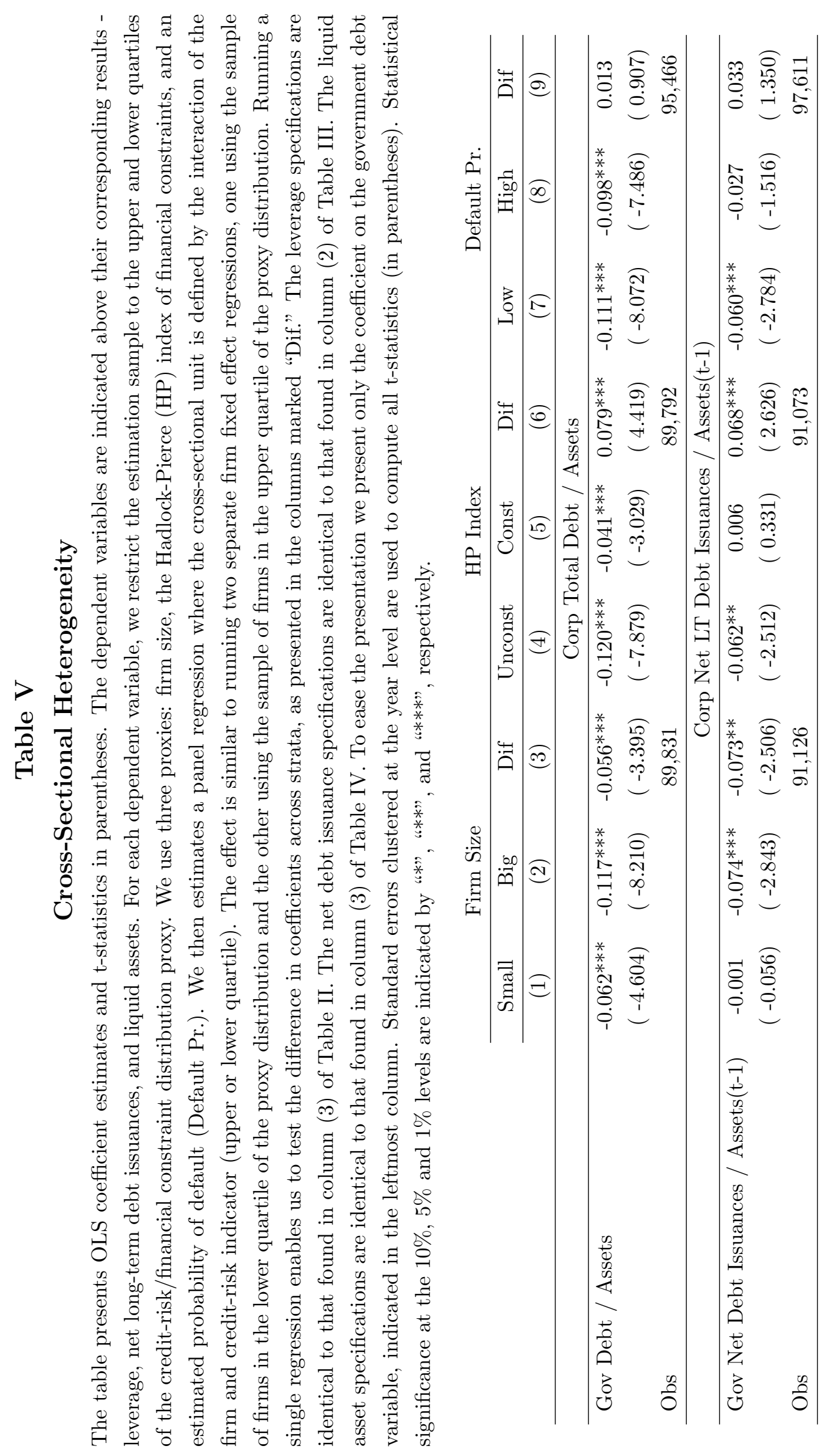




\section{Table VI}

\section{Credit Spreads and Government Leverage}

The table presents OLS estimates and t-statistics in parentheses from time series regressions. The dependent variable is the BAA-AAA yield spread on corporate bonds and the data annual observations from 1926 to 2010 or 2012 depending on whether government leverage is normalized by Assets or GDP, respectively. All right side variables are contemporaneous with the dependent variable and are formally defined in Appendix A. Newey-West standard errors assuming two non-zero lags are used to compute all t-statistics (in parentheses). Statistical significance at the 10\%, 5\% and $1 \%$ levels are indicated by "**, “**”, and “***», respectively.

\begin{tabular}{|c|c|c|c|c|c|c|}
\hline & (1) & $(2)$ & $(3)$ & $(4)$ & $(5)$ & (6) \\
\hline Ln(Gov Debt / GDP $)$ & $\begin{array}{c}-0.640 \text { *** } \\
(-2.993)\end{array}$ & & $\begin{array}{c}-0.482^{* * *} \\
(-3.702)\end{array}$ & & $\begin{array}{c}-0.396^{* * *} \\
(-2.644)\end{array}$ & \\
\hline Ln(Gov Debt / Assets) & & $\begin{array}{c}-0.498^{* * *} \\
(-2.905)\end{array}$ & & $\begin{array}{c}-0.287^{* * *} \\
(-3.259)\end{array}$ & & $\begin{array}{c}-0.217^{*} \\
(-1.935)\end{array}$ \\
\hline T-Bond - T-Bill Spread & & & $\begin{array}{c}0.132^{* * *} \\
(3.076)\end{array}$ & $\begin{array}{c}0.091^{*} \\
(1.897)\end{array}$ & $\begin{array}{l}0.129 * * \\
(2.347)\end{array}$ & $\begin{array}{c}0.101^{*} \\
(1.690)\end{array}$ \\
\hline Equity Volatility & & & $\begin{array}{c}4.865^{* * *} \\
(9.353)\end{array}$ & $\begin{array}{c}4.970^{* * *} \\
(8.880)\end{array}$ & $\begin{array}{c}4.682^{* * *} \\
(8.705)\end{array}$ & $\begin{array}{c}4.871^{* * *} \\
(9.088)\end{array}$ \\
\hline Log Real Growth of GDP & & & $\begin{array}{c}-0.009 \\
(-0.556)\end{array}$ & $\begin{array}{c}-0.003 \\
(-0.229)\end{array}$ & $\begin{array}{c}-0.001 \\
(-0.070)\end{array}$ & $\begin{array}{c}0.001 \\
(0.072)\end{array}$ \\
\hline EBIT / Assets & & & & & $\begin{array}{c}0.015 \\
(0.513)\end{array}$ & $\begin{array}{c}0.019 \\
(0.606)\end{array}$ \\
\hline Default Probability & & & & & $\begin{array}{c}2.556 \\
(1.419)\end{array}$ & $\begin{array}{c}2.246 \\
(1.174)\end{array}$ \\
\hline Adjusted $\mathrm{R}^{2}$ & 0.096 & 0.153 & 0.628 & 0.622 & 0.650 & 0.633 \\
\hline Obs & 93 & 85 & 87 & 85 & 87 & 85 \\
\hline
\end{tabular}




\section{Table VII}

\section{Intermediary Asset Composition and Government Leverage}

The table presents OLS coefficient estimates and t-statistics in parentheses. Each panel presents results from six different regressions. The dependent variable is indicated by the panel title and is measured relative to the total financial assets of the financial institution, denoted at the top of the columns. For example, the first panel, denoted Corporate Loans, Bonds, \& Commercial Paper, presents the estimates from regressions of the ratio of loans, corporate bonds, and commercial paper asset holdings to total financial assets on the ratio of federal debt held by the public to total assets of the unregulated sector. Columns (1) and (2) present the results for US chartered depository institutions. Columns (3) and (4) present the results for US insurance companies. Columns (5) and (6) present the results for state and local pensions. Odd numbered columns correspond to univariate regressions, even numbered columns correspond to multivariate regressions with the following controls: three month T-bill rate, BAA-Treasury bond spread, inflation, equity market return, real GDP growth, corporate EBIT / assets, corporate intangible assets / assets, and corporate market-to-book ratio. All right hand side variables are contemporaneous with the dependent variable. All variables are in first differnces. Newey-West standard errors assuming two non-zero lags are used to compute all t-statistics (in parentheses). Statistical significance at the $10 \%, 5 \%$ and $1 \%$ levels are indicated by “*”, “**”, and "***”, respectively.

Change in (Corporate Lending / Assets)

\begin{tabular}{lcccccc} 
& \multicolumn{6}{c}{ Change in (Corporate Lending / Assets) } \\
\cline { 2 - 7 } & \multicolumn{7}{c}{ Banks } & \multicolumn{2}{c}{ Insurance } & \multicolumn{2}{c}{ Public Pensions } \\
\cline { 2 - 7 } & $(1)$ & $(2)$ & $(3)$ & $(4)$ & $(5)$ & $(6)$ \\
\hline Gov Debt / Assets & $-0.054^{* * *}$ & $-0.055^{* * *}$ & $-0.041^{*}$ & $-0.039^{*}$ & $-0.127^{*}$ & -0.088 \\
& $(-3.437)$ & $(-3.276)$ & $(-1.871)$ & $(-1.932)$ & $(-1.776)$ & $(-1.469)$ \\
\hline Obs & 72 & 72 & 75 & 75 & 65 & 65 \\
\hline & \multicolumn{7}{c}{ Treasuries } \\
\hline Gov Debt / Assets & $0.180^{* * *}$ & $0.195^{* * *}$ & $0.183^{* * *}$ & $0.200^{* * *}$ & 0.065 & 0.082 \\
& $(4.045)$ & $(3.724)$ & $(9.758)$ & $(10.344)$ & $(1.267)$ & $(1.622)$ \\
\hline Obs & 76 & 76 & 75 & 75 & 65 & 65 \\
\hline \multirow{5}{*}{ Gov Debt / Assets } & 0.017 & 0.007 & 0.019 & 0.020 & -0.016 & -0.001 \\
& $(1.437)$ & $(0.613)$ & $(1.552)$ & $(1.501)$ & $(-0.870)$ & $(-0.032)$ \\
\hline Obs & 65 & 65 & 65 & 65 & 65 & 65 \\
\hline
\end{tabular}




\section{Table VIII}

\section{Foreign Holdings}

The table presents OLS coefficient estimates and t-statistics in parentheses. The dependent variable is corporate leverage, defined as the ratio of all interest-bearing debt to the book value of total assets. Foreign Holdings Wedge is the difference between foreign holdings of treasuries and foreign holdings of corporate debt. All right hand side variables are contemporaneous with the dependent variable and the regression is estimated in first difference form. All variables are formally defined in Appendix A. NeweyWest standard errors assuming two non-zero lags are used to compute all t-statistics (in parentheses). Statistical significance at the $10 \%, 5 \%$ and $1 \%$ levels are indicated by "**, “**”, and "***”, respectively.

\begin{tabular}{|c|c|c|}
\hline & \multicolumn{2}{|c|}{$\Delta$ Corporate Leverage } \\
\hline & $(1)$ & $(2)$ \\
\hline Gov Debt / Assets & $\begin{array}{c}-0.026^{* * *} \\
(-2.833)\end{array}$ & $\begin{array}{l}-0.034^{* *} \\
(-2.119)\end{array}$ \\
\hline Gov Debt / Assets x Foreign Holdings Wedge & $\begin{array}{c}-0.006^{* *} \\
(-2.513)\end{array}$ & $\begin{array}{c}-0.004^{*} \\
(-1.720)\end{array}$ \\
\hline Foreign Holdings Wedge & $\begin{array}{c}0.144 \\
(1.450)\end{array}$ & $\begin{array}{c}0.091 \\
(0.986)\end{array}$ \\
\hline \multicolumn{3}{|l|}{ Macroeconomic Variables } \\
\hline T-Bill Return & & $\begin{array}{c}-0.021 \\
(-0.232)\end{array}$ \\
\hline BAA - T-Bond Spread & & $\begin{array}{c}0.205 \\
(1.134)\end{array}$ \\
\hline Inflation & & $\begin{array}{c}0.017 \\
(0.541)\end{array}$ \\
\hline Equity Market Return & & $\begin{array}{c}0.001 \\
(0.092)\end{array}$ \\
\hline Log Real Growth of GDP & & $\begin{array}{c}-0.056^{*} \\
(-1.938)\end{array}$ \\
\hline Gov Exp / Assets & & $\begin{array}{c}-0.014 \\
(-0.343)\end{array}$ \\
\hline \multicolumn{3}{|l|}{ Firm Characteristics } \\
\hline EBIT / Assets & & $\begin{array}{c}-0.181^{*} \\
(-1.937)\end{array}$ \\
\hline Intangible Assets / Assets & & $\begin{array}{c}-0.098 \\
(-0.520)\end{array}$ \\
\hline Market-to-Book Asset Ratio & & $\begin{array}{c}0.221 \\
(0.218)\end{array}$ \\
\hline Obs & 84 & 81 \\
\hline
\end{tabular}




\section{Table IX}

\section{Corporate Investment}

The table presents OLS coefficient estimates and t-statistics in parentheses. Panel A presents annual time series regressions The dependent variable is corporate investment in period $t$ divided by total assets in period t-1. All flow variables are contemporaneous with the dependent variable; stock variables and interest rates are lagged one period. Panel B presents firm level fixed effect regressions. The dependent variable is corporate investment divided by start of period total assets. We restrict the estimation sample to the upper and lower quartiles of the credit risk/financial constraint distribution proxy. We use three proxies: firm size, the Hadlock-Pierce (HP) index of financial constraints, and an estimated probability of default (Default Pr.). We then estimates a panel regression where the cross-sectional unit is defined by the interaction of the firm and credit-risk indicator (upper or lower quartile). The investment specifications are identical to that found in column (3) of Table IV. To ease the presentation we present only the coefficient on the government debt variable, indicated in the leftmost column. NeweyWest standard errors assuming two non-zero lags are used to compute all t-statistics (in parentheses). Statistical significance at the $10 \%, 5 \%$ and $1 \%$ levels are indicated by "**, "“**”, and "***”, respectively.

Panel A: Annual Time Series Regressions

\begin{tabular}{|c|c|c|c|c|}
\hline & & & & \\
\hline & (1) & $(2)$ & $(3)$ & $(4)$ \\
\hline Gov Net Debt Issuances / Assets(t-1) & $-0.113^{* * *}$ & $-0.123^{* * *}$ & $-0.094^{* * *}$ & $-0.048^{* *}$ \\
\hline & $(-5.753)$ & $(-4.557)$ & $(-4.362)$ & $(-2.527)$ \\
\hline \multicolumn{5}{|l|}{ Macroeconomic Variables } \\
\hline \multirow[t]{2}{*}{ T-Bill Return } & & $0.166^{* *}$ & $0.308^{* * *}$ & $0.124^{* *}$ \\
\hline & & $(2.400)$ & $(5.639)$ & $(2.329)$ \\
\hline \multirow[t]{2}{*}{ BAA - T-Bond Spread } & & $-0.790 * * *$ & 0.009 & -0.053 \\
\hline & & $(-2.880)$ & $(0.029)$ & $(-0.247)$ \\
\hline \multirow[t]{2}{*}{ Inflation } & & $0.163^{* * *}$ & 0.089 & $0.157^{* * *}$ \\
\hline & & $(3.331)$ & $(1.599)$ & $(3.046)$ \\
\hline \multirow[t]{2}{*}{ Gov Exp / Assets } & & 0.037 & 0.039 & 0.004 \\
\hline & & $(1.419)$ & $(1.546)$ & $(0.198)$ \\
\hline \multicolumn{5}{|l|}{ Firm Characteristics } \\
\hline \multirow[t]{2}{*}{ Net Income / Assets } & & & $0.524^{* * *}$ & $0.363^{* * *}$ \\
\hline & & & $(5.739)$ & $(4.581)$ \\
\hline \multirow[t]{2}{*}{ Market-to-Book Asset Ratio } & & & $1.957^{* *}$ & $1.592^{* *}$ \\
\hline & & & $(2.011)$ & $(2.443)$ \\
\hline \multirow[t]{2}{*}{ Lag Investment / Assets } & & & & $0.406^{* * *}$ \\
\hline & & & & $(5.831)$ \\
\hline Obs & 85 & 83 & 83 & 83 \\
\hline
\end{tabular}




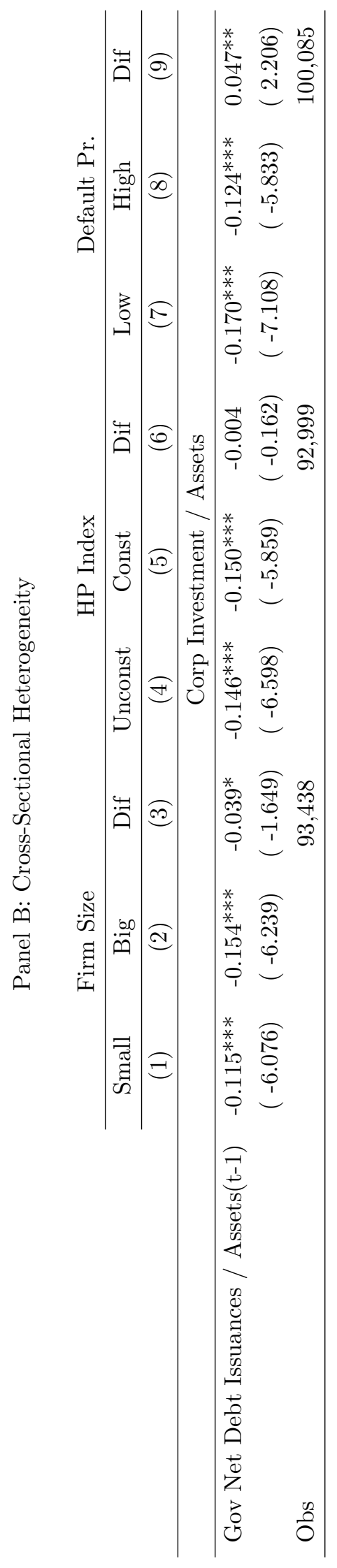

